\author{
RESEARCH ARTICLE \\ 10.1029/2019JB018099 \\ Key Points: \\ - High-temperature deformation \\ experiments on cores of \\ FOAMGLAS $^{\infty}$ explore melt foam \\ rheological and outgassing \\ behaviors \\ - Deforming melt foams show strain \\ weakening, hardening, and \\ localization, but undergo little or no \\ outgassing (i.e., are impermeable) \\ - Crystal-free bubble-rich silicic lavas \\ outgas inefficiently, allowing for \\ sustained low effective viscosities \\ and efficient transport
}

Supporting Information:

- Supporting Information S1

Correspondence to:

A. G. Ryan,

aryan@eoas.ubc.ca

Citation:

Ryan, A. G., Russell, J. K., Heap, M. J., Kolzenburg, S., Vona, A., \& Kushnir, A R. L. (2019). Strain-dependent rheology of silicate melt foams: Importance for outgassing of silicic lavas. Journal of Geophysical Research: Solid Earth, 124, 8167-8186. https://doi.org/10.1029/ 2019JB018099

Received 29 MAY 2019 Accepted 22 JUL 2019

Accepted article online 30 JUL 2019 Published online 20 AUG 2019

(C)2019. American Geophysical Union. All Rights Reserved.

\section{Strain-Dependent Rheology of Silicate Melt Foams: Importance for Outgassing of Silicic Lavas}

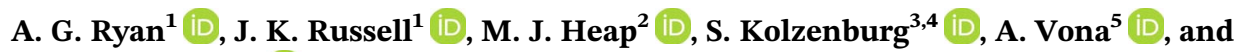 \\ A. R. L. Kushnir ${ }^{2}$ (D) \\ ${ }^{1}$ Volcanology and Petrology Laboratory, EOAS, University of British Columbia, Vancouver, British Columbia, Canada, \\ ${ }^{2}$ Institut de Physique de Globe de Strasbourg (UMR 7516 CNRS, Université de Strasbourg/EOST), Strasbourg, France, \\ ${ }^{3}$ Department of Earth and Planetary Sciences, McGill University, Quebec, Canada, ${ }^{4}$ Department für Geo- und \\ Umweltwissenschaften, Ludwig-Maximilians-Universität, München, Germany, ${ }^{5}$ Dipartimento di Scienze, Università \\ degli Studi Roma Tre, Roma, Italy
}

\begin{abstract}
Outgassing of volcanic systems is a ubiquitous phenomenon. Yet the mechanisms facilitating gas escape from vesiculating magmas and lavas remain poorly understood. Pervasive outgassing is thought to depend on the efficient and abundant formation of permeable pathways. Here we present results from experiments designed to identify the conditions and mechanisms needed to form such permeable pathways. We use a foamed silicate melt $\left(\right.$ FOAMGLAS $\left.^{\circledR}\right)$ in our experiments as a proxy for natural vesicular melts. FOAMGLAS ${ }^{\circledast}$ cores are compressed under a range of temperatures and strain rates, and results are evaluated against the state of melt relaxation (parameterized using the Deborah number). We find that foam microstructure and rheological and outgassing behaviors evolve with strain and as a function of melt relaxation state. Relaxed melt foams harden during deformation but remain impermeable. As foams become less relaxed at higher strain rate and/or melt viscosity, they show complex responses to deformation (strain weakening and hardening) yet remain impermeable. Strain localization and formation of high-permeability bands occur only in highly strained, unrelaxed foams. However, these bands are thin and oriented perpendicular to the principal stress, resulting in limited outgassing. Permeable pathways do not readily form in foams; rather, high-porosity melts are "persistently impermeable." Our results imply that vesicular silicic lavas may not outgas as efficiently as previously thought. Instead, sustained impermeability allows the lava to maintain low effective viscosities, and to flow extended distances. In addition, pore pressures may rise in deforming impermeable lavas, perhaps priming the lava for later explosive behavior.
\end{abstract}

\section{Introduction}

Large rhyolitic lava flows, such as those found at Newberry Volcano (OR, USA), Medicine Lake Volcano, and Mono-Inyo Craters (CA, USA), commonly feature interiors of dense obsidian (rhyolitic glass), encased by vesicular glassy carapaces (e.g., Castro et al., 2002; Eichelberger et al., 1986; Fink et al., 1992; Fink \& Manley, 1987). The process that explains, both, the large areal extents of these silicic lavas and the characteristic abundance of dense obsidian remains a topic of vigorous debate. There have been few modern opportunities to study the eruption and emplacement of rhyolite lavas (e.g., Chaitén Volcano (Chile), 2008-2009; Castro et al., 2012; Puyehue Cordón-Caulle volcanic complex (Chile), 2011-2012; Schipper et al., 2013). Observations made on these recent effusive eruptions suggest that the interiors of the lavas are thermally insulated and remain close to eruption temperature (e.g., Farquharson et al., 2015; Tuffen et al., 2013). However, even at eruption temperatures ( 700-900 ${ }^{\circ} \mathrm{C}$; Farquharson et al., 2015; Schipper et al., 2013; Yoshimura et al., 2019), silicic lavas have high viscosities (>10 8 Pa s; Giordano et al., 2008) that make it challenging to produce areally extensive lavas of dense rhyolitic obsidian (e.g., Eichelberger et al., 1986; Fink et al., 1992).

Vesiculation resulting in high bubble contents provides a means of lowering the effective viscosity of the rhyolitic magmas (Mader et al., 2013, and references therein). For example, vesiculation within the conduit (Eichelberger et al., 1986) or syneruption vesiculation at the surface (Fink et al., 1992; Magnall et al., 2018) has the potential to create a gas-filled, bubble-rich silicic lava having a substantially lower viscosity than the melt. A lower viscosity could support longer transport distances of thermally insulated lavas. The characteristic dense obsidian lavas we observe, however, require that the high-vesicularity lavas have lost pore fluid 
(a)
Existing models

Pervasive outgassing

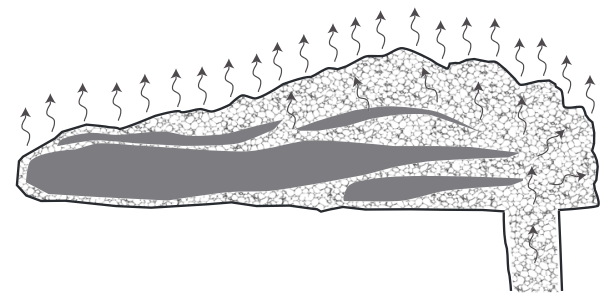

Sustained high permeability
Repeated permeability creation

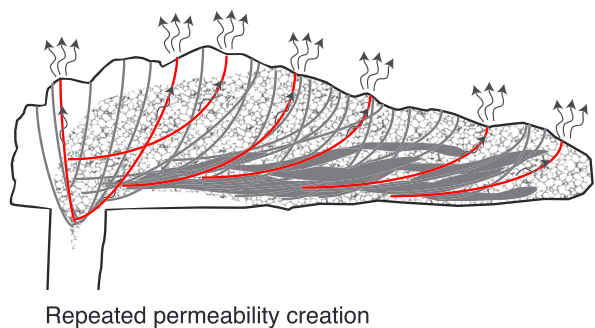

(b)

Figure 1. Existing models for outgassing of silicic lavas. (a) "Permeable foam" model put forward by Eichelberger et al. (1986): lava vesiculates in the subsurface to form a permeable foam. Sustained high permeability supports continuous outgassing (arrows) as the lava exits the conduit and flows across the surface. Eventually sufficient outgassing reduces lava porosity to create dense, nonvesicular regions in the lava (obsidian; grey regions). (b) Formation of ephemeral permeable pathways: lava vesiculates near or at the surface. In contrast to (a), the foam is not highly permeable. Permeable pathways (e.g., interconnected bubble channels, melt fractures) form (red lines) and collapse (grey lines), allowing for cyclic outgassing (arrows; e.g., Castro, Cordonnier, et al., 2012; Yoshimura et al., 2019). Volatiles are drained from the lava to produce nonvesicular zones.

and have reduced porosities after flowing extended distances. This could be achieved by efficient outgassing during emplacement, leading to bubble collapse and subsequent deflation.

Eichelberger et al. (1986) proposed that obsidian flows originally erupt as high-permeability bubbly melts (i.e., "permeable foams") having low effective viscosities that outgas continuously during emplacement (Figure 1a). Alternative models suggest that vesicular lavas experience outgassing by the formation of ephemeral permeable pathways_interconnected bubble channels (e.g., Okumura et al., 2009; Yoshimura et al., 2019) and/or melt fractures (e.g., Cabrera et al., 2011; Castro, Cordonnier, et al., 2012, Castro et al., 2014; Kushnir et al., 2017; Okumura et al., 2013; Saubin et al., 2016; Schipper et al., 2013; Shields et al., 2016; Tuffen et al., 2003; Figure 1b). These models envisage periods of efficient outgassing followed by collapse and annealing, leading to a loss of permeability; repeated formation of ephemeral pathways eventually drain the volatiles from the system to produce a degassed, dense, obsidian-dominated lava.

Existing models for the emplacement of silicic lavas, therefore, require that the initial bubbly lavas are permeable or rapidly develop permeable pathways during flow (Figure 1). High-temperature experimental studies, often using hydrated natural glasses as the starting material, have sought to identify the processes, conditions, and time scales required to form permeable pathways, and to facilitate pervasive outgassing. The results from these experimental studies are diverse-in some instances, the melt walls separating bubbles remain intact until very high porosities are attained, implying that bubble-rich melts remain impermeable (Burgisser et al., 2017; Lindoo et al., 2016; Ryan et al., 2015; Takeuchi et al., 2009). Conversely, other studies show bubble coalescence to occur, suggesting a means of creating transitory permeable pathways (Bagdassarov et al., 1996; Burgisser et al., 2017; Burgisser \& Gardner, 2005; Castro et al., 2012; Giachetti et al., 2019; Gonnermann et al., 2017; Lindoo et al., 2016; Martel \& IaconoMarziano, 2015; Stevenson et al., 1997). Simple shearing has been shown in some experiments to increase the efficacy of coalescence, even at low porosities (e.g., Caricchi et al., 2011; Okumura et al., 2009). In addition, fracturing of the melt joins bubbles in some experiments, resulting in localized outgassing (e.g., Kushnir et al., 2017; Okumura et al., 2010; Shields et al., 2014). Finally, other experiments record vesicle shrinkage due to resorption or diffusive loss of the $\mathrm{H}_{2} \mathrm{O}$ fluid within the bubbles (e.g., McIntosh et al., 2014; von Aulock et al., 2017; Westrich \& Eichelberger, 1994; Yoshimura \& Nakamura, 2008, 2010). This wide range in behavior observed in parallel experimental studies reflects the complexities of bubble growth and loss in natural melts.

Here we present a series of high-temperature deformation experiments designed to explore the rheological behavior of bubbly silicate melts with a focus on processes that allow for gas retention or loss during flow. A key component of our study is a unique experimental material that allows to circumvent many of the issues presented by the use of natural materials: FOAMGLAS ${ }^{\circledast}$ is a crystal-free soda lime glass foam that is texturally homogenous, bubble-rich and, because all bubble walls are intact, impermeable (Ryan et al., 2019). 
We uniaxially compressed FOAMGLAS ${ }^{\circledR}$ at high temperatures (above the glass transition temperature) to high strain at two strain rates $\left(2.5 \times 10^{-3}\right.$ and $\left.2.5 \times 10^{-5} \mathrm{~s}^{-1}\right)$. Our experimental data comprise mechanical (stress-strain curves) and acoustic emission (AE) data collected during deformation, analyses of sample microstructure postdeformation, and measurements of final porosities and permeabilities. These data show that the impermeable melt foam cores often remain impermeable, despite being deformed to high strain (60\% axial strain). High-permeability compaction bands form at extreme conditions (high strain, high deformation rates, and melt viscosities) but result in only limited outgassing. Permeable pathways, therefore, do not form readily in FOAMGLAS ${ }^{\circledR}$ melts subjected to the investigated experimental conditions. Our experimental data suggest that silicic lavas are "persistently impermeable.” We explore the impact of inefficient outgassing on emplacement dynamics of rhyolitic lava flows.

\section{Materials}

FOAMGLAS $^{\circledast}$ (HLB 2400) is a high-porosity, closed-cell glass insulation manufactured by Owens Corning Corporation. Here we include a brief description of the material and readers are referred to Ryan et al. (2019) for full descriptions of its physical, thermal, and transport properties.

FOAMGLAS $^{\circledast}$ has a total fractional porosity of 0.91 and is impermeable. It can be cut, cored, handled, and heated to high temperature without significant microscopic or macroscopic fracturing, or other changes to its physical properties. When prepared as cylindrical $2.4-\mathrm{cm}$ diameter $\times 5.2-\mathrm{cm}$ length cores, as in this study, the isolated porosity of the cores is 0.85 . The difference between the total and isolated porosities $(0.06)$ is a measure of the bubbles that intersect the surface of the core, rather than bubbles that have become connected by FOAMGLAS ${ }^{\circledast}$ production or sample preparation processes.

The solid component of FOAMGLAS ${ }^{\circledR}$ is crystal-free soda lime glass, synthesized from recycled glass and other natural materials, including sand, dolomite, and lime (Ryan et al., 2019). We previously measured melt viscosities $\left(\eta_{0}\right)$ by concentric cylinder and micropenetration viscometry, and used results to fit for the adjustable parameters in the Vogel-Fulcher-Tammann equation $\left(\log _{10} \eta_{0}=A+B /(T-C)\right.$, where $T$ is the temperature in kelvin, $A=-2.14, B=4238.96$, and $C=498.45$; Ryan et al., 2019). We use our solution to model the temperature-dependent melt viscosity of FOAMGLAS ${ }^{\circledR}$. The modeled rheological glass transition temperature $\left(T_{g}\right)$, taken as the temperature at which melt viscosity is $10^{12} \mathrm{~Pa} \mathrm{~s}$, is $525^{\circ} \mathrm{C}$.

Bubbles in FOAMGLAS ${ }^{\circledast}$ contain gas $\left(>99.5 \% \mathrm{CO}_{2}\right)$, are homogenously distributed within the glass, and are bimodal in size: large bubbles (100-275 $\mu \mathrm{m}$ in radius) are volumetrically dominant. These bubbles are subrounded to polygonal in shape, and separated from one another by thin, nearly straight, or slightly curved glass films. Glass walls have an average thickness of $\sim 25 \pm 15 \mu \mathrm{m}$. Numerous small bubbles $(<25 \mu \mathrm{m}$ in radius) sit within these glass films, or at triple junctions between large bubbles. Small bubbles are round to subrounded. Cores of FOAMGLAS ${ }^{\circledast}$ have been shown to retain the pore gas throughout deformation (Ryan et al., 2019).

When heated to temperatures up to $600{ }^{\circ} \mathrm{C}$, FOAMGLAS ${ }^{\circledast}$ is stable-the measured dimensions and the total and isolated porosities of cores do no change significantly as a result of heating to temperatures above $T_{g}$. However, exposure to high temperatures and air will change the color of FOAMGLAS ${ }^{\circledast}$ from black to green, as trace amounts of iron in the soda lime melt oxidize. The distribution of oxidized (green) regions in cooled cores can be used to qualitatively assess whether FOAMGLAS ${ }^{\circledast}$ remained impermeable while at high temperatures, and to determine the orientation, shape, and extent of any permeable pathways formed during deformation (see section 6).

\section{Methods}

\subsection{Deformation Experiments}

We performed unconfined, uniaxial compression experiments to deform FOAMGLAS ${ }^{\circledR}$ at temperatures $(T$; ${ }^{\circ} \mathrm{C}$ ) between 540 and $580{ }^{\circ} \mathrm{C}$, at strain rates of $2.5 \times 10^{-3}$ and $2.5 \times 10^{-5} \mathrm{~s}^{-1}\left(\dot{\varepsilon}, \mathrm{s}^{-1}\right)$, and to variable axial strain ( $\varepsilon$; fractional; Table 1). These experiments were performed using the low-load Volcanic Deformation Rig (VDR) at the University of British Columbia (Canada) (Quane et al., 2004; Figure S1). Samples were placed between two ceramic pistons within a tube furnace and heated at $5{ }^{\circ} \mathrm{C} / \mathrm{min}$ to the experimental $T$. The furnace was controlled by one K-type thermocouple and monitored by three K-type thermocouples positioned 
Table 1

Experimental Conditions and Physical Properties of Experimental Products

\begin{tabular}{|c|c|c|c|c|c|c|c|c|c|c|c|c|c|c|c|}
\hline \multirow[b]{2}{*}{ Number } & \multirow[b]{2}{*}{$T\left({ }^{\circ} \mathrm{C}\right)$} & \multirow[b]{2}{*}{$\varepsilon$} & \multicolumn{6}{|c|}{ Change $^{\mathrm{a}}$} & \multicolumn{7}{|c|}{ Final $^{\mathrm{b}}$} \\
\hline & & & $\Delta l(\mathrm{~cm})$ & $1 \sigma$ & $\Delta d(\mathrm{~cm})$ & $1 \sigma$ & $\Delta V_{d}\left(\mathrm{~cm}^{3}\right)$ & p.u. & $\phi_{t}$ & p.u. & $\phi_{i}$ & p.u. & $V_{p}\left(\mathrm{~cm}^{3}\right)$ & p.u. & $k\left(\mathrm{~m}^{2}\right)^{\mathrm{c}}$ \\
\hline \multicolumn{16}{|c|}{ Strain rate $=2.5 \times 10^{-5} \mathrm{~s}^{-1}$} \\
\hline $116^{\mathrm{d}}$ & 546 & 0.10 & -0.52 & 0.00 & 0.04 & 0.03 & -1.77 & 0.49 & 0.91 & 0.02 & 0.84 & 0.02 & 19.73 & 0.02 & - \\
\hline $110^{\mathrm{d}}$ & 552 & 0.10 & -0.54 & 0.00 & 0.06 & 0.03 & -1.53 & 0.52 & 0.91 & 0.02 & 0.84 & 0.02 & 19.76 & 0.03 & $\ll 10^{-18}$ \\
\hline 340 & 554 & 0.10 & -0.53 & 0.00 & 0.06 & 0.03 & -1.48 & 0.57 & 0.92 & 0.02 & 0.84 & 0.02 & 20.11 & 0.02 & - \\
\hline $121^{\mathrm{d}}$ & 545 & 0.20 & -1.01 & 0.00 & 0.08 & 0.06 & -3.49 & 0.94 & 0.90 & 0.04 & 0.85 & 0.04 & 18.52 & 0.02 & - \\
\hline $108^{d}$ & 553 & 0.20 & -0.98 & 0.00 & 0.11 & 0.07 & -2.85 & 1.16 & 0.90 & 0.05 & 0.83 & 0.05 & 18.35 & 0.03 & $\ll 10^{-18}$ \\
\hline 343 & 555 & 0.20 & -1.08 & 0.00 & 0.16 & 0.06 & -2.55 & 1.00 & 0.91 & 0.04 & 0.84 & 0.04 & 18.93 & 0.02 & - \\
\hline $117^{\mathrm{d}}$ & 546 & 0.30 & -1.42 & 0.00 & 0.15 & 0.06 & -4.26 & 0.98 & 0.90 & 0.05 & 0.82 & 0.05 & 15.85 & 0.02 & - \\
\hline $106^{\mathrm{d}}$ & 549 & 0.30 & -1.45 & 0.00 & 0.16 & 0.08 & -4.65 & 1.22 & 0.89 & 0.05 & 0.84 & 0.05 & 17.37 & 0.04 & $\ll 10^{-18}$ \\
\hline $104^{\mathrm{d}}$ & 546 & 0.40 & -1.92 & 0.00 & 0.18 & 0.12 & -6.86 & 1.65 & 0.88 & 0.08 & 0.84 & 0.08 & 15.43 & 0.03 & $\ll 10^{-18}$ \\
\hline $118^{\mathrm{d}}$ & 548 & 0.40 & -1.79 & 0.01 & 0.20 & 0.13 & -5.83 & 1.84 & 0.88 & 0.08 & 0.85 & 0.08 & 16.36 & 0.02 & - \\
\hline 341 & 557 & 0.40 & -2.10 & 0.00 & 0.39 & 0.19 & -5.23 & 2.63 & 0.90 & 0.12 & 0.83 & 0.12 & 16.66 & 0.03 & - \\
\hline $115^{\mathrm{d}}$ & 543 & 0.50 & -2.28 & 0.00 & 0.27 & 0.14 & -7.39 & 1.70 & 0.88 & 0.09 & 0.83 & 0.09 & 13.95 & 0.02 & $\ll 10^{-18}$ \\
\hline $120^{\mathrm{d}}$ & 547 & 0.50 & -2.30 & 0.00 & 0.34 & 0.19 & -6.79 & 2.41 & 0.88 & 0.12 & 0.82 & 0.12 & 14.92 & 0.02 & - \\
\hline $112^{\mathrm{d}}$ & 545 & 0.60 & -2.61 & 0.01 & 0.42 & 0.17 & -7.80 & 2.08 & 0.87 & 0.11 & 0.79 & 0.11 & 13.60 & 0.04 & $\ll 10^{-18}$ \\
\hline $119^{\mathrm{d}}$ & 547 & 0.60 & -2.55 & 0.01 & 0.38 & 0.16 & -7.54 & 1.90 & 0.88 & 0.10 & 0.82 & 0.10 & 13.27 & 0.03 & - \\
\hline 337 & 554 & 0.60 & -3.13 & 0.00 & 0.68 & 0.26 & -8.96 & 2.71 & 0.86 & 0.14 & 0.77 & 0.14 & 12.57 & 0.03 & - \\
\hline \multicolumn{16}{|c|}{ Strain rate $=2.5 \times 10^{-3} \mathrm{~s}^{-1}$} \\
\hline 316 & 551 & 0.10 & -0.52 & 0.00 & 0.06 & 0.03 & -1.36 & 0.50 & 0.90 & 0.03 & 0.83 & 0.03 & 19.59 & 0.02 & - \\
\hline 339 & 554 & 0.10 & -0.51 & 0.00 & 0.06 & 0.03 & -1.32 & 0.60 & 0.92 & 0.03 & 0.83 & 0.03 & 19.83 & 0.03 & - \\
\hline 322 & 554 & 0.20 & -1.09 & 0.00 & 0.12 & 0.05 & -3.32 & 0.78 & 0.88 & 0.03 & 0.81 & 0.03 & 17.82 & 0.02 & - \\
\hline 338 & 555 & 0.20 & -1.07 & 0.00 & 0.11 & 0.04 & -3.42 & 0.63 & 0.90 & 0.03 & 0.82 & 0.03 & 17.88 & 0.03 & - \\
\hline 335 & 552 & 0.30 & -1.59 & 0.00 & 0.12 & 0.06 & -5.95 & 0.83 & 0.90 & 0.04 & 0.80 & 0.04 & 15.11 & 0.03 & - \\
\hline 323 & 553 & 0.30 & -1.59 & 0.00 & 0.11 & 0.03 & -6.03 & 0.43 & 0.88 & 0.02 & 0.80 & 0.02 & 15.06 & 0.02 & - \\
\hline 333 & 554 & 0.40 & -2.07 & 0.00 & 0.15 & 0.08 & -7.29 & 1.04 & 0.88 & 0.06 & 0.78 & 0.06 & 11.92 & 0.02 & - \\
\hline 328 & 554 & 0.40 & -2.06 & 0.00 & 0.18 & 0.05 & -6.96 & 0.67 & 0.88 & 0.04 & 0.76 & 0.04 & 12.25 & 0.01 & - \\
\hline 329 & 554 & 0.50 & -2.57 & 0.00 & 0.18 & 0.07 & -9.65 & 0.71 & 0.85 & 0.04 & 0.74 & 0.05 & 9.86 & 0.02 & - \\
\hline 332 & 554 & 0.50 & -2.56 & 0.00 & 0.18 & 0.08 & -9.58 & 0.84 & 0.85 & 0.05 & 0.75 & 0.05 & 9.99 & 0.02 & - \\
\hline 348 & 551 & 0.60 & -3.09 & 0.00 & 0.26 & 0.04 & -12.39 & 0.39 & 0.81 & 0.02 & 0.61 & 0.02 & 7.48 & 0.03 & - \\
\hline 330 & 553 & 0.60 & -3.07 & 0.01 & 0.24 & 0.09 & -11.65 & 0.78 & 0.82 & 0.06 & 0.67 & 0.06 & 7.63 & 0.03 & - \\
\hline 308 & 554 & 0.60 & -3.04 & 0.00 & 0.16 & 0.04 & -13.31 & 0.40 & 0.81 & 0.02 & 0.70 & 0.02 & 8.15 & 0.02 & - \\
\hline 336 & 554 & 0.60 & -3.06 & 0.00 & 0.19 & 0.08 & -13.34 & 0.71 & 0.84 & 0.05 & 0.68 & 0.05 & 8.14 & 0.02 & - \\
\hline $361^{\mathrm{e}}$ & 553 & 0.60 & - & - & - & - & - & - & - & - & - & - & - & - & $\ll 10^{-18 \mathrm{f}}$ \\
\hline $362^{\mathrm{e}}$ & 555 & 0.60 & - & - & - & - & - & - & - & - & - & - & - & - & $7.3 \times 10^{-13 \mathrm{~g}}$ \\
\hline \multicolumn{16}{|c|}{ Strain rate $=2.5 \times 10^{-3} \mathrm{~s}^{-1}$} \\
\hline $311^{\mathrm{e}}$ & 540 & 0.60 & - & - & - & - & - & - & - & - & - & - & - & - & - \\
\hline $353^{\mathrm{e}}$ & 543 & 0.60 & - & - & - & - & - & - & - & - & - & - & - & - & - \\
\hline 359 & 546 & 0.60 & -3.08 & 0.00 & 0.19 & 0.11 & -13.27 & 0.99 & 0.81 & 0.07 & 0.62 & 0.07 & 7.28 & 0.02 & - \\
\hline 346 & 549 & 0.60 & -3.09 & 0.00 & 0.20 & 0.16 & -13.25 & 1.44 & 0.81 & 0.10 & 0.64 & 0.10 & 7.72 & 0.06 & - \\
\hline 354 & 557 & 0.60 & -3.08 & 0.00 & 0.25 & 0.06 & -12.75 & 0.58 & 0.83 & 0.04 & 0.69 & 0.04 & 8.47 & 0.08 & - \\
\hline 355 & 561 & 0.60 & -3.08 & 0.00 & 0.23 & 0.05 & -12.86 & 0.49 & 0.83 & 0.03 & 0.73 & 0.03 & 8.85 & 0.01 & - \\
\hline 351 & 563 & 0.60 & -3.07 & 0.00 & 0.31 & 0.05 & -12.10 & 0.52 & 0.84 & 0.03 & 0.72 & 0.03 & 9.34 & 0.08 & - \\
\hline 350 & 566 & 0.60 & -3.09 & 0.00 & 0.35 & 0.07 & -11.92 & 0.70 & 0.83 & 0.04 & 0.73 & 0.04 & 9.64 & 0.08 & - \\
\hline 356 & 570 & 0.60 & -3.08 & 0.00 & 0.32 & 0.07 & -12.17 & 0.66 & 0.84 & 0.04 & 0.76 & 0.04 & 9.80 & 0.02 & - \\
\hline 349 & 572 & 0.60 & -3.10 & 0.00 & 0.41 & 0.11 & -11.16 & 1.05 & 0.82 & 0.06 & 0.74 & 0.06 & 10.08 & 0.03 & - \\
\hline 357 & 575 & 0.60 & -3.09 & 0.00 & 0.33 & 0.12 & -12.04 & 1.12 & 0.83 & 0.07 & 0.79 & 0.07 & 10.22 & 0.02 & - \\
\hline 358 & 577 & 0.60 & -3.10 & 0.00 & 0.42 & 0.19 & -11.30 & 1.80 & 0.84 & 0.11 & 0.80 & 0.11 & 11.09 & 0.02 & - \\
\hline 352 & 581 & 0.60 & -3.10 & 0.00 & 0.56 & 0.09 & -9.90 & 0.90 & 0.86 & 0.05 & 0.76 & 0.05 & 11.47 & 0.08 & - \\
\hline
\end{tabular}

Note. Including temperature $(T)$, axial strain ( $\varepsilon$; fractional), and strain rate. Physical properties of experimental products, including changes in length, diameter, and dimensional volume $\left(\Delta l, \Delta d\right.$, and $\Delta V_{d}$, respectively). Also final measured total and isolated porosities ( $\phi_{t}$ and $\phi_{i}$, respectively; fractional), cumulative pore volume $\left(V_{p}\right)$, and permeability $(k)$. Standard deviations $(1 \sigma)$ and propagated uncertainties (p.u.) are included.

${ }^{\mathrm{a}}$ Measured with digital calipers. Average initial $l, d$, and $V_{d}$ are $5.19 \pm 0.02 \mathrm{~cm}, 2.46 \pm 0.04 \mathrm{~cm}$, and $24.73 \pm 0.80 \mathrm{~cm}^{3}$, respectively. ${ }^{\mathrm{b}} \phi_{t}=1-\left(m / V_{d} \rho_{\text {glass }}\right)$, where $m$ is the mass $(\mathrm{g}), V_{d}$ is the dimensional volume measured by calipers, and $\rho_{\text {glass }}$ is the density of the glass $\left(2.41 \mathrm{~g} / \mathrm{cm}^{3}\right) ; \phi_{i}=\left(V_{s} \rho_{\text {glass }}-m\right) /\left(V_{d} \rho_{\text {glass }}\right)$, where $V_{s}$ is the skeletal volume measured by helium pycnometry; $V_{p}=V_{s}-\left(m / \rho_{\text {glass }}\right)$. Average initial $\phi_{t}, \phi_{i}$, and $V_{p}$ are $0.91 \pm 0.006,0.85 \pm 0.003$, and

$21.03 \pm 0.66 \mathrm{~cm}^{3}$, respectively. ${ }^{\mathrm{c}}$ Detection limit of permeameter is $10^{-18} \mathrm{~m}^{2}$. See text for details. ${ }^{\mathrm{d}}$ Samples unloaded after deformation but before cooling ("rebound" samples). ${ }^{\mathrm{e}}$ Samples not included in quantitative analyses. ${ }^{\mathrm{f}}$ Permeability measured perpendicular and ${ }^{\mathrm{g}}$ parallel to plane of strain localization. 
level with the bottom, middle, and top of the samples. The thermal gradient in this region $(\sim 5.2 \mathrm{~cm})$ was $1-5{ }^{\circ} \mathrm{C}(<1 \%$ experimental temperature). Samples dwelled for $45 \mathrm{~min}$ at the experimental $T$ to ensure that they were relaxed and thermally homogenous prior to deformation. Sample cores were then deformed at constant $\dot{\varepsilon}$ of $2.5 \times 10^{-3}$ or $2.5 \times 10^{-5} \mathrm{~s}^{-1}$, to $\varepsilon$ of 0.10 to 0.60 . A linear variable displacement transducer beneath the bottom moving plate measured transient sample shortening (displacement), and a load cell (maximum load: $1,136 \mathrm{~kg}$ ) at the top of the sample assembly measured load throughout deformation (Quane et al., 2004; Figure S1).

Following deformation, the furnace was cooled at $5{ }^{\circ} \mathrm{C} / \mathrm{min}$. The time between the end of deformation and cooling below $T_{g}\left(525^{\circ} \mathrm{C}\right)$ was 3-11 min depending on the experimental temperature (i.e., samples were ${ }^{15}-55^{\circ} \mathrm{C}$ above $T_{g}$ ). In most experiments samples were cooled while in contact with the upper piston. In some experiments (noted in Table 1) the samples were unloaded prior to cooling, and expanded vertically in the absence of a load (Ryan et al., 2019).

In three experiments a piezoelectric transducer, part of a MISTRAS PCI-2 AE system, was attached to the VDR load cell to record the output of AE throughout deformation (Figure S1). A threshold frequency of $45 \mathrm{~dB}$ was used to eliminate noise from the VDR's cooling system and step motor. These data are used qualitatively, in concert with mechanical data and microstructures, to understand processes occurring within bubble walls during deformation.

\subsection{Postdeformation Characterization}

Final sample length $(l ; \mathrm{cm})$ and mass $(m ; \mathrm{g})$ were measured following deformation (Table 1$)$. Sample diameter $(d ; \mathrm{cm})$ was measured 10 times along the length of the cores to account for bulging/barreling, and then averaged (Table 1). The final dimensional volumes (volume of glass + isolated bubbles + bubbles at sample surface; $V_{d} ; \mathrm{cm}^{3}$ ) were calculated from these measurements (Table 1). The skeletal volumes (volume of glass + isolated bubbles; $V_{s} ; \mathrm{cm}^{3}$ ) were measured using a Micromeritics AccuPyc II 1340 helium pycnometer. Total $\left(\phi_{t}\right.$; fractional) and isolated ( $\phi_{i}$; fractional) porosities of each core were calculated from $V_{d}, V_{s}$, and the density of the glass component of FOAMGLAS ${ }^{\circledast}\left(\rho_{\text {glass }}=2.41 \mathrm{~g} / \mathrm{cm}^{3}\right.$; Ryan et al., 2019; Table 1). Uncertainties in all measurements are reported in Table 1.

The total volume of bubbles in each core, or the total pore volume of each sample $\left(V_{p} ; \mathrm{cm}^{3}\right)$, was determined from measurements of $V_{s}, m$, and $\rho_{\text {glass }}$ (Table 1). Because FOAMGLAS ${ }^{\circledR}$ has a high gas:solid ratio, the differences between initial and final $\phi_{t}$ of highly strained samples may be small (Ryan et al., 2019). The normalized change in $V_{p}$ (i.e., $\% \Delta V_{p}=\Delta V_{p} / V_{p \_ \text {initial }} \times 100 \%$ ), however, has the same magnitude as $\varepsilon$. Therefore, $\Delta V_{p}$ is a more sensitive metric to quantify the change in total pore volume following deformation.

The permeabilities of eight deformed cores were estimated using a benchtop nitrogen permeameter at the Institut de Physique du Globe de Strasbourg (University of Strasbourg, France; see Heap, Kushnir, et al., 2017 and Kushnir et al. (2018) for permeameter details, methods, and supporting theory). Six measurements were made on small cylindrical subcores $(2.0-\mathrm{cm}$ diameter $\times 2.4-4.6-\mathrm{cm}$ length) drilled from samples deformed at $10^{-5} \mathrm{~s}^{-1}$ to variable strain (0.10-0.60; Table 1). Core lengths are oriented parallel to the compression direction $\left(\sigma_{1}\right.$; i.e., permeability was measured parallel to $\left.\sigma_{1}\right)$. Following our previous method, (1) sample surfaces were coated in silicone sealant to minimize gas flow along the irregular surface of the core; (2) a confining pressure of $1 \mathrm{MPa}$ was used; (3) a transient pulse decay method was used, with an initial upstream fluid pressure of 2,000 mbar and an atmospheric downstream pressure; and (4) test times were $<16$ hr (Ryan et al., 2019).

Two additional permeability measurements were conducted on smaller cylindrical subcore (1.1-cm diameter $\times 2.0-3.0$-cm length) drilled from samples deformed at $10^{-3} \mathrm{~s}^{-1}$ to high strain (0.60; Table 1 and Figure S2). One of these subcores, which was drilled parallel to $\sigma_{1}$, was measured using the pulse decay method described above. The other, drilled perpendicular to $\sigma_{1}$, was measured using the steady state method. This measurement was performed in the same setup described above, also under a confining pressure of $1 \mathrm{MPa}$. Six steady state volumetric flow rate measurements (in the range $10-40 \mathrm{~mL} / \mathrm{min}$ ) were taken for different pressure differentials, from 10 to 40 mbar. These data were then used to calculate permeability using Darcy's law (see Heap, Kushnir, et al. (2017) and Kushnir et al. (2018) for more details). We note 

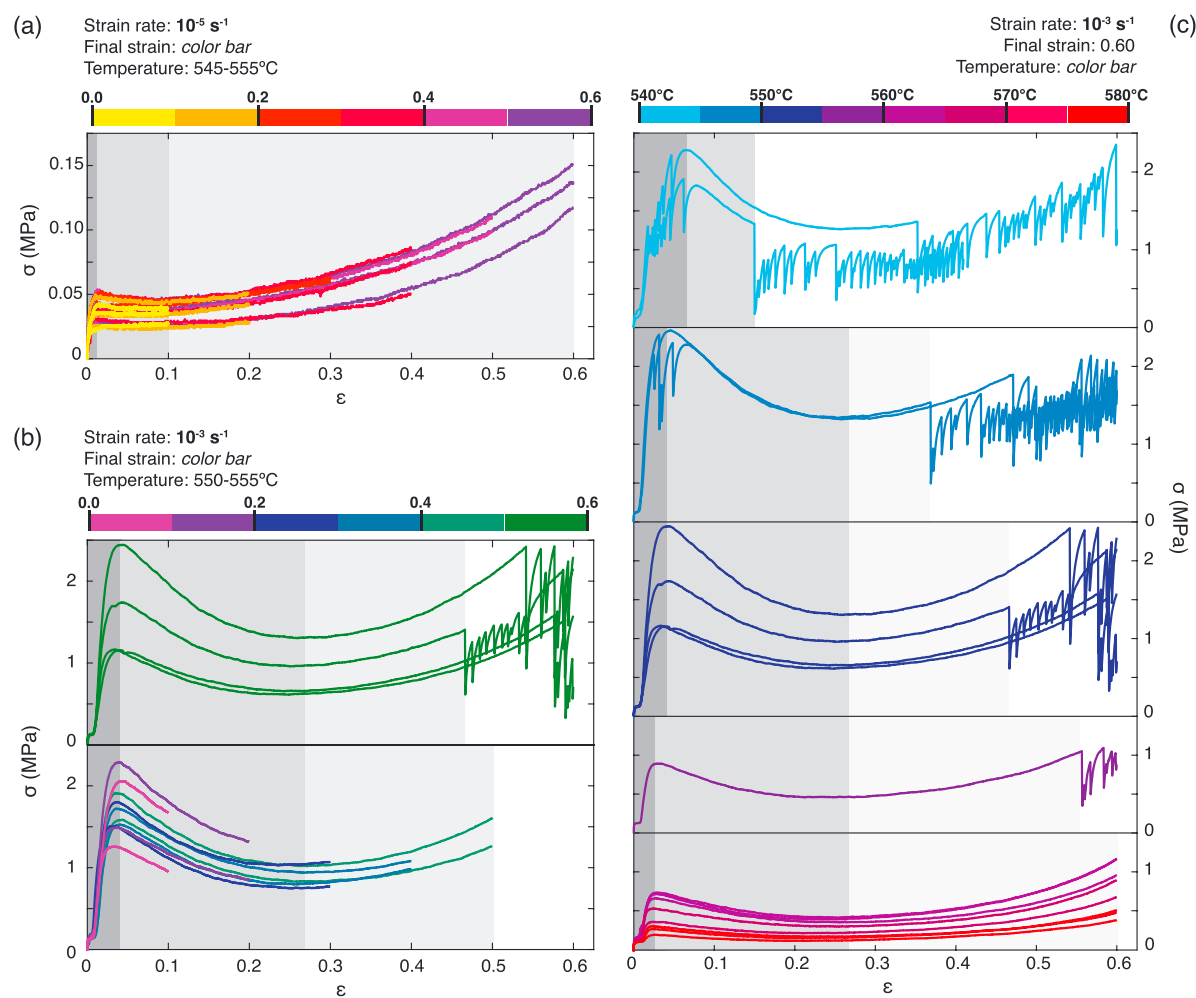

Figure 2. Mechanical data from deformation experiments plotted as load stress $(\sigma)$ versus instrumental strain $(\varepsilon)$. Grey panels demarcate periods of loading (dark grey), strain weakening (medium grey), and strain hardening (light grey). (a) High-strain experiments conducted at $545-555^{\circ} \mathrm{C}$ at $2.5 \times 10^{-5} \mathrm{~s}^{-1}$ to variable final strain (color bar). The initial $(\varepsilon<0.02)$ steep rise in stress is an experimental artifact resulting from sample loading. The load stress curve has an initial peak value, then decreases slightly (i.e., strain weakening) before rising markedly (i.e., strain hardening). Small temperature differences between shift plateaus of curves up or down. (b) Experiments conducted at $550-555{ }^{\circ} \mathrm{C}$ at $2.5 \times 10^{-3} \mathrm{~s}$ to variable final strain (color bar). Samples show pronounced strain weakening followed by strain hardening. At high strains $(0.45<\varepsilon<0.6)$ sharp repetitive stress drops occur (curves from samples compressed to $\varepsilon=0.6$ are offset within figure for clarity). (c) Experiments conducted at $2.5 \times 10^{-3} \mathrm{~s}^{-1}$ to 0.60 strain at temperatures from $540{ }^{\circ} \mathrm{C}$ (light blue) to $581{ }^{\circ} \mathrm{C}$ (red; color bar). Curves that show stress drops are grouped by temperature range and offset for clarity. Below $550{ }^{\circ} \mathrm{C}$ samples fracture during loading. Below $560{ }^{\circ} \mathrm{C}$ samples deform viscously, followed by stress drops. As temperature increases stress drops occur at higher strains. No stress drops occur in samples deformed above $560{ }^{\circ} \mathrm{C}$. Initial peak $\sigma$ values and the magnitude of strain weakening $(0.04<\varepsilon<0.30)$ decrease as temperature increases. At temperatures above $555{ }^{\circ} \mathrm{C}$ strain hardening $(\varepsilon>0.30)$ causes the final $\sigma$ values to exceed the initial peak $\sigma$.

that, due to the high permeability of the sample, Forchheimer correction was required to correct for the influence of turbulent fluid flow (i.e., inertial effects; Rust \& Cashman, 2004) on the calculated permeability (see Heap, Kushnir, et al. (2017) and Kushnir et al. (2018)).

Following physical property measurements, deformed cores were cut to thin wafers oriented parallel to $\sigma_{1}$, and imaged using scanning electron microscopy.

\section{Results of Deformation Experiments}

\subsection{High Strain, Variable Strain Rate}

Figures $2 \mathrm{a}$ and $2 \mathrm{~b}$ show mechanical data (stress ( $\sigma$; MPa)-strain $(\varepsilon)$ curves) for samples deformed to variable final strain $(\varepsilon=0.10-0.60)$ at two deformation (strain) rates $\left(\dot{\varepsilon} \sim 10^{-5} \mathrm{~s}^{-1}, \dot{\varepsilon} \sim 10^{-3} \mathrm{~s}^{-1}\right)$ at $545-555^{\circ} \mathrm{C}$ (Table 1). At the same $\dot{\varepsilon}-T$ conditions the mechanical behavior of samples is consistent-curves overlap. Small variations in the experimental temperature (Table 1) cause curves to shift up or down slightly. 


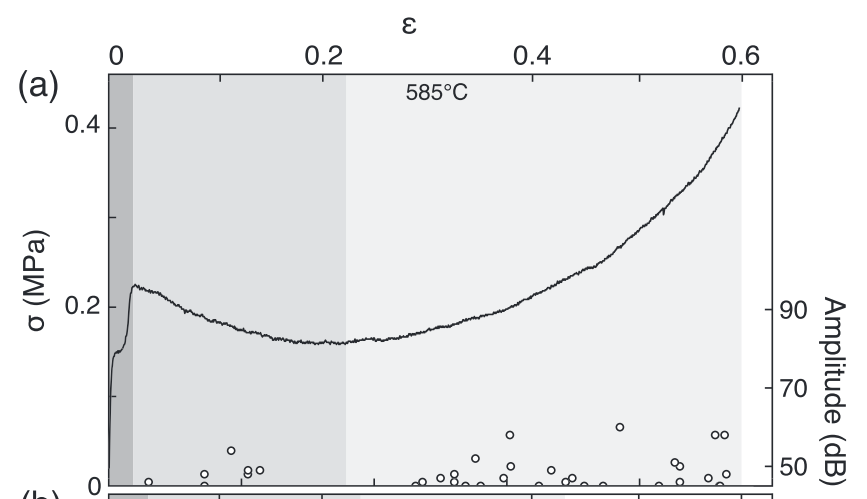

(b)

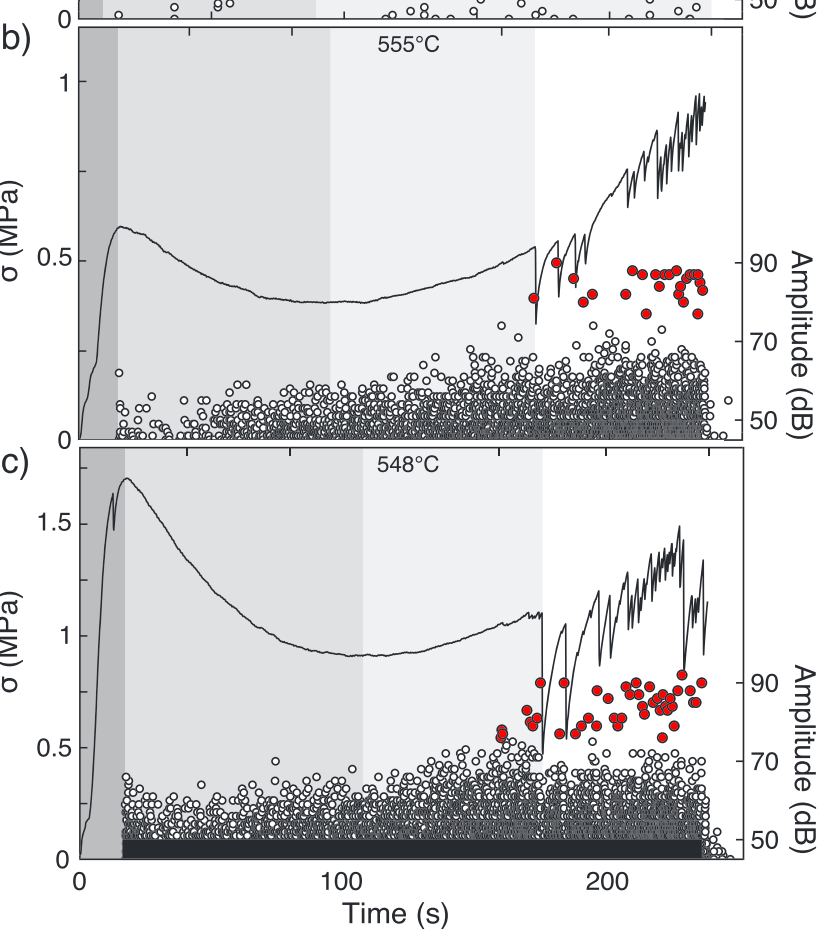

Figure 3. Acoustic emissions (AE) during deformation. Solid curves are stress ( $\sigma ; \mathrm{MPa})$ against time (s) and strain ( $\varepsilon$; fractional) data for samples deformed at $2.5 \times 10^{-3} \mathrm{~s}^{-1}$ to 0.60 strain. Symbols show the amplitude of $\mathrm{AE}$ events against time (i.e., strain) for events recorded after sample loading. $\mathrm{AE}$ events $>75 \mathrm{~dB}$ (high-AE; red circles) correlate with stress drops in mechanical data. Grey panels demarcate periods of loading, strain weakening, strain hardening, and the onset of stress drops. (a) Experiment at $585^{\circ} \mathrm{C}$. No stress drops occur. Few AE events $<75 \mathrm{~dB}$ (low-AE; white circles) occur. (b) Experiment at $555^{\circ} \mathrm{C}$. The number and amplitude of low-AE events reach a minimum at $\varepsilon \sim 0.10$ (middle of strain weakening), and a stable maximum at $\varepsilon \sim 0.35$ (middle of strain hardening).

(c) Experiment at $548{ }^{\circ} \mathrm{C}$. Sample fractures during loading. Pattern of low-AE events the same as in (b). Following large stress drops, and high-AE events, the number of low-AE events sharply decreases, then sharply increases back to the plateau level.
In cores deformed at a deformation rate of $10^{-5} \mathrm{~s}^{-1}$ (Figure 2a) $\sigma$ reaches an initial peak value at $\varepsilon \sim 0.02$ after which $(0.02<\varepsilon<0.10)$ stress decreases slightly. This indicates minor strain weakening. Strain hardening-an increase in stress with strain-occurs as deformation continues. Curves are smooth and show no sudden stress drops. In all experiments final $\sigma$ values are larger (up to 3 times) than the initial peak $\sigma$ values.

In cores deformed at a deformation rate of $10^{-3} \mathrm{~s}^{-1}$ (Figure $2 \mathrm{~b}$ ) $\sigma$ reaches an initial peak value after loading $(\varepsilon \sim 0.04)$, then shows pronounced strain weakening $(0.04<\varepsilon<0.30)$ before showing strain-hardening behavior. Repetitive stress drops are recorded at high $\varepsilon(0.45<\varepsilon<0.60)$. In all but two high-strain experiments, final $\sigma$ values are less than the initial peak $\sigma$ values.

In summary, the melt foam shows a complex mechanical response to deformation, including strain weakening and strain hardening behaviors, as well as stress drops. Foams deformed at different strain rates show different patterns in their strain-dependent behavior. Increased $\dot{\varepsilon}$ causes (1) a rise in the maximum $\sigma$ value, (2) higher magnitudes and longer durations of strain weakening behavior, (3) delays in the onset of strain hardening, and (4) stress drops at high values of $\varepsilon$, indicating strain localization. We also note that $\sigma$ measured just after loading is often the maximum value in samples deformed at high $\dot{\varepsilon}$, whereas in samples deformed at low $\dot{\varepsilon}$ the $\sigma$ value measured just after loading is near the minimum.

\subsection{High Strain Rate, Variable Temperature}

A second set of experiments was used to establish the sensitivity of straindependent mechanical behavior to changes in $T$ (i.e., melt viscosity). Cores were deformed at $10^{-3} \mathrm{~s}$, to high strain $(\varepsilon=0.60)$ over a wider range of temperatures: $T=540-581^{\circ} \mathrm{C}$ (Table 1$)$.

Figure $2 \mathrm{c}$ shows $\sigma-\varepsilon$ curves grouped by $T$. Where $T<550{ }^{\circ} \mathrm{C}$, the mechanical behavior is punctuated by stress drops during loading $(\varepsilon<0.05)$. Following loading $\sigma-\varepsilon$ curves are smooth, showing strain weakening and hardening before further stress drops are observed. At $550{ }^{\circ} \mathrm{C}<T<560$ ${ }^{\circ} \mathrm{C}$ sample $\sigma$ changes smoothly with $\varepsilon$ until stress drops are observed. Across the data set, as $T$ increases, the onset of the stress drops occurs at greater $\varepsilon$. No stress drops are observed in experiments at $>560{ }^{\circ} \mathrm{C}$.

Within these experiments the initial peak $\sigma$ and the magnitude of strain weakening decrease as $T$ increases. At $T>555^{\circ} \mathrm{C}$ strain hardening causes the final $\sigma$ values to exceed the initial peak $\sigma$.

\subsection{Acoustic Emissions During Deformation}

In a third set of experiments we recorded $\mathrm{AE}$ events during deformation at $10^{-3} \mathrm{~s}^{-1}$ to high strain $(\varepsilon=0.60)$. Figure 3 shows the correlation in time between recorded $\mathrm{AE}$ events and mechanical data (stress-time curves) for experiments performed at $548{ }^{\circ} \mathrm{C}, 555^{\circ} \mathrm{C}$, and $585^{\circ} \mathrm{C}$. AE events with amplitudes $>75 \mathrm{~dB}$ (red circles; "high-AE") correspond to sudden large stress drops. AE events with amplitudes $<75 \mathrm{~dB}$ (white circles; "low-E”) are infrequent during the experiment conducted at high $T$, indicating that, in all experiments, low-AE events are not caused by the noise of the VDR (Figure S1).

At $585{ }^{\circ} \mathrm{C}$ the sample shows minor strain weakening and pronounced strain hardening behavior after 0.20 strain (Figure 3a). Throughout deformation few low-AE events were recorded.

At $555{ }^{\circ} \mathrm{C}$ the sample shows greater strain weakening and stress drops at high strain (Figure $3 \mathrm{~b}$ ). At $548{ }^{\circ} \mathrm{C}$ strain weakening is pronounced and the stress drops occur during loading and at high strain 
Table 2

Modeled Viscosities

\begin{tabular}{llllll}
\hline Number & $T\left({ }^{\circ} \mathrm{C}\right)$ & $\varepsilon$ & $\begin{array}{c}\log _{10} \eta_{0} \\
(\mathrm{~Pa} \mathrm{~s}))^{\mathrm{a}}\end{array}$ & $\begin{array}{l}\log _{10} \eta_{e} \\
(\mathrm{~Pa} \mathrm{~s})\end{array}$ & $\begin{array}{c}\log _{10} \\
\eta_{r}{ }^{\mathrm{c}}\end{array}$ \\
\hline
\end{tabular}

\begin{tabular}{|c|c|c|c|c|c|}
\hline \multicolumn{6}{|c|}{ Strain rate $=2.5 \times 10^{-5} \mathrm{~s}^{-1}$} \\
\hline 116 & 546 & 0.10 & 11.1 & 9.2 & -1.9 \\
\hline 110 & 552 & 0.10 & 10.8 & 9.2 & -1.7 \\
\hline 340 & 554 & 0.10 & 10.8 & 9.0 & -1.7 \\
\hline 121 & 545 & 0.20 & 11.1 & 9.3 & -1.8 \\
\hline 108 & 553 & 0.20 & 10.8 & 9.2 & -1.6 \\
\hline 343 & 555 & 0.20 & 10.7 & 9.1 & -1.7 \\
\hline 117 & 546 & 0.30 & 11.1 & 9.4 & -1.7 \\
\hline 106 & 549 & 0.30 & 11.0 & 9.4 & -1.6 \\
\hline 104 & 546 & 0.40 & 11.1 & 9.5 & -1.6 \\
\hline 118 & 548 & 0.40 & 11.0 & 9.5 & -1.5 \\
\hline 341 & 557 & 0.40 & 10.6 & 9.3 & -1.3 \\
\hline 115 & 543 & 0.50 & 11.2 & 9.6 & -1.6 \\
\hline 120 & 547 & 0.50 & 11.0 & 9.6 & -1.5 \\
\hline 112 & 545 & 0.60 & 11.1 & 9.8 & -1.4 \\
\hline 119 & 547 & 0.60 & 11.0 & 9.7 & -1.3 \\
\hline 337 & 554 & 0.60 & 10.8 & 9.7 & -1.1 \\
\hline \multicolumn{6}{|c|}{ Strain rate $=2.5 \times 10^{-3} \mathrm{~s}^{-1}$} \\
\hline 316 & 551 & 0.10 & 10.9 & 8.8 & -2.0 \\
\hline 339 & 554 & 0.10 & 10.8 & 8.6 & -2.2 \\
\hline 322 & 554 & 0.20 & 10.8 & 8.7 & -2.0 \\
\hline 338 & 555 & 0.20 & 10.7 & 8.5 & -2.2 \\
\hline 335 & 552 & 0.30 & 10.8 & 8.5 & -2.3 \\
\hline 323 & 553 & 0.30 & 10.8 & 8.6 & -2.2 \\
\hline 333 & 554 & 0.40 & 10.8 & 8.6 & -2.2 \\
\hline 328 & 554 & 0.40 & 10.8 & 8.6 & -2.1 \\
\hline 329 & 554 & 0.50 & 10.8 & 8.8 & -2.0 \\
\hline 332 & 554 & 0.50 & 10.8 & 8.7 & -2.1 \\
\hline $348^{\mathrm{d}}$ & 551 & 0.60 & 10.9 & 9.0 & -1.9 \\
\hline $330^{\mathrm{d}}$ & 553 & 0.60 & 10.8 & 8.7 & -2.1 \\
\hline $308^{d}$ & 554 & 0.60 & 10.8 & 8.8 & -2.0 \\
\hline $336^{d}$ & 554 & 0.60 & 10.8 & 8.8 & -2.0 \\
\hline \multicolumn{6}{|c|}{ Strain rate $=2.5 \times 10^{-3} \mathrm{~s}^{-1}$} \\
\hline $354^{\mathrm{d}}$ & 557 & 0.60 & 10.6 & 8.6 & -2.0 \\
\hline 355 & 561 & 0.60 & 10.5 & 8.6 & -1.8 \\
\hline 351 & 563 & 0.60 & 10.4 & 8.6 & -1.8 \\
\hline 350 & 566 & 0.60 & 10.3 & 8.6 & -1.7 \\
\hline 356 & 570 & 0.60 & 10.2 & 8.4 & -1.7 \\
\hline 349 & 572 & 0.60 & 10.1 & 8.5 & -1.5 \\
\hline 357 & 575 & 0.60 & 10.0 & 8.3 & -1.7 \\
\hline 358 & 577 & 0.60 & 9.9 & 8.3 & -1.6 \\
\hline 352 & 581 & 0.60 & 9.8 & 8.2 & -1.6 \\
\hline
\end{tabular}

Note. Melt viscosity $\left(\eta_{0}\right)$ and final effective and relative viscosities $\left(\eta_{e}\right.$ and $\eta_{r}$ ). Samples that fractured during loading are not included.

${ }^{a} \log _{10} \eta_{0}=-2.14+4238.96 /(T(K)-498.45)$ (Ryan et al., 2019).

${ }^{\mathrm{b}}$ At final $\varepsilon$, or just prior to first stress drop. $\quad{ }^{\mathrm{c}} \eta_{r}=\eta_{e} / \eta_{0} . \quad{ }^{\mathrm{d}}$ Samples show stress drops at high $\varepsilon$.
(Figure 3c). High-AE events correspond to stress drops in the mechanical data. However, low-AE events recorded during deformation are not correlated with the mechanical response of the melt foam: the number and amplitude of low-AE events reach a minimum during strain weakening and a stable maximum (plateau) at $\varepsilon \sim 0.35$, after the onset of strain hardening at $\varepsilon \sim 0.25$. The onset of the stress drops in the mechanical behavior is also not preceded by a change in the number or amplitude of low-AE events (Figure 3c).

\subsection{Effective and Relative Viscosities}

We calculate the effective and relative viscosities ( $\eta_{e}$ and $\eta_{r}$, respectively) as a means of quantitatively comparing deformational behavior between experiments. Model values of $\eta_{e}$ approximate the tangent to the $\sigma-\dot{\varepsilon}$ curve at point $i$ and are computed as

$$
\eta_{e}=\frac{\sigma_{i}}{\dot{\varepsilon}_{i}}=\frac{\left(\operatorname{mean}\left(F_{i-j}, F_{i+j}\right) / A_{0}\right)}{\left(\frac{\operatorname{mean}\left(x_{i+j}, x_{i-j}\right) / l_{0}}{\operatorname{mean}\left(t_{i+j}, t_{i-j}\right)}\right)}
$$

where $F$ is the measured load $(\mathrm{N}), A_{0}$ is the original contact area $\left(\mathrm{m}^{2}\right), l_{0}$ is the initial length (m), $x$ is the measured displacement $(\mathrm{m}), t$ is the elapsed time (s), $i$ is the index, and $j$ is half the prescribed interval.

The relative viscosity $\left(\eta_{r}\right)$ is computed as

$$
\eta_{r}=\frac{\eta_{e}}{\eta_{0}}
$$

where $\eta_{0}$ is the temperature-dependent melt viscosity, predicted by the Vogel-Fulcher-Tammann equation for the melt (section 2) at the experimental temperature (Table 2).

Values of $\eta_{e}$ and $\eta_{r}$ are plotted against $\varepsilon$ in Figures $4 \mathrm{a}$ and $4 \mathrm{~b}$. The shapes of curves reflect the presence and magnitude of strain weakening and strain hardening, as in Figure 2. In addition, at fixed $\varepsilon, \eta_{e}$ is greatest at low $\dot{\varepsilon}$, and decreases as $\dot{\varepsilon}$ and $T$ increase. As a result $\eta_{r}$ is at a minimum in samples deformed quickly. Finally, the effective viscosity of the foam is 1-2.5 orders of magnitude less than the melt viscosity.

There have been few other studies of the effect of fluid-filled isolated bubbles on the bulk viscosity of silicic (rhyolitic) magmas. Bagdassarov and Dingwell (1992) measured the effective viscosities of foamed rhyolitic melts (total porosities $=0.25-0.65$ ) and found the differences between the magma and melt viscosities to be 1 order of magnitude. Vona et al. (2016) also measured foamed rhyolitic melts with similar porosities (total porosities $=0.40-0.65$ ) and calculated effective viscosities 1.1-1.6 orders of magnitude less than the melt viscosity for the imposed experi-
a (2018) showed less porous rhyolitic melts (total porosities $=0.15-0.40$ ) mental strain rates. Finally, Sicola (2018) showed less porous rhyolitic melts (total porosities $=0.15-0.40$ ) to have bulk viscosities $0.2-1$ order of magnitude less than the melt viscosity. In all three of these studies the range of modeled effective viscosities, which were calculated using modifications of the Gent perfect slip equation rather than an incremental treatment of the $\sigma-\dot{\varepsilon}$ data we have used here (equation (1)), was attributed to the differing initial porosities of the samples (Bagdassarov \& Dingwell, 1992; Sicola, 2018; Vona et al., 2016). In contrast to these studies, the differences in the relative viscosity of FOAMGLAS ${ }^{\circledR}$ reflect changes in the total axial strain (Figure 4), a feature that we were only able to investigate because of the homogenous nature of the sample material. 
(a)

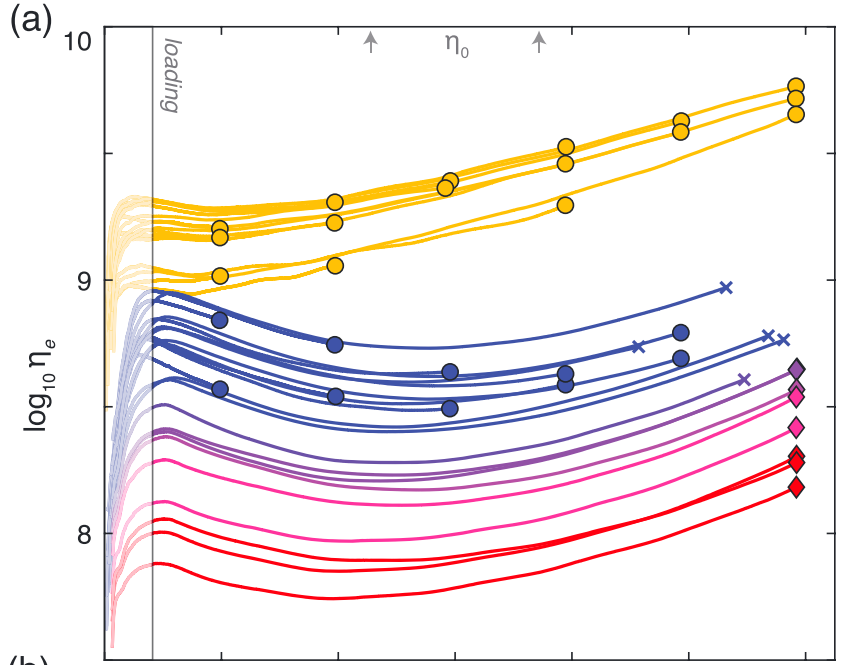

(b)

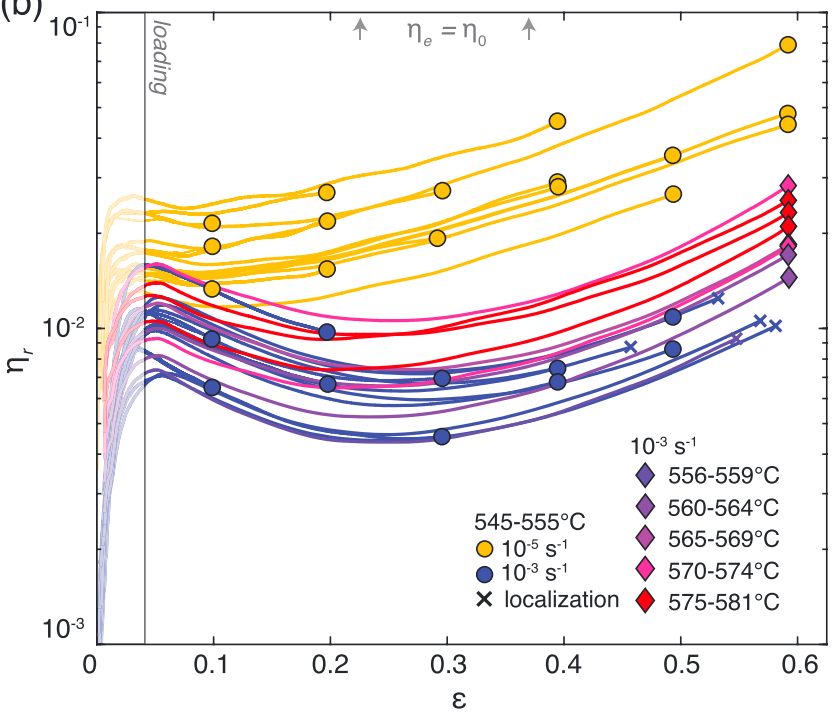

Figure 4. Transient effective $\left(\eta_{e}\right)$ and relative $\left(\eta_{r}\right)$ viscosities. Curves show (a) $\eta_{e}$ and (b) $\eta_{r}$ against strain ( $\varepsilon$; fractional) for all experiments (legend). Symbols show final $\varepsilon-\eta_{e}$ values (Table 2). For samples that showed stress drops and strain localization crosses mark the maximum $\varepsilon-\eta_{e}$ values prior to the first stress drop. At fixed $\varepsilon, \eta_{e}$ is greatest for samples deformed slowly, and lowest for samples deformed quickly and at high $T$. Curve shapes reflect the presence and magnitude of strain weakening and strain hardening (Figure 2). After accounting for the effect of temperature on deformational response, samples deformed slowly show the greatest values of $\eta_{r}$ at fixed $\varepsilon$.

\section{Physical Properties of Deformed Cores}

As FOAMGLAS ${ }^{\circledast}$ cores deform, their geometry (diameter and volume) and porosity (total and isolated) change as functions of $\varepsilon$, $\dot{\varepsilon}$, and $T$ (Figures 5a-5c and Table 1).

Sample diameters increase (i.e., samples bulge) with $\varepsilon$. Strain rate and temperature influence the propensity for bulging (Figure 5a, top): in samples deformed quickly $\left(10^{-3} \mathrm{~s}^{-1}\right)$, the maximum change in sample diameter is $<10 \%$. In contrast, samples deformed slowly $\left(10^{-5} \mathrm{~s}^{-1}\right)$ show a greater increase in sample diameter, up to $30 \%$. At a constant strain rate cores bulge more with increasing $T$.

Final dimensional volumes $\left(V_{d}\right)$ reflect both sample shortening (change in $l$ is equivalent to $\varepsilon$ ) and bulging. At the same strain, samples that show the greatest increase in $d$ therefore show the least volume reduction (Figure 5a, bottom). The maximum reduction in $V_{d}(\sim 60 \%)$ occurs in samples deformed quickly at low $T$.

Total porosity $\left(\phi_{t}\right)$ gives the fraction of samples occupied by all pore space (isolated + connected bubbles + bubbles at sample surfaces; Figure $5 b$, top). $\phi_{t}$ values decrease as $\varepsilon$ increases. The change in $\phi_{t}$ is greatest in samples deformed quickly and at low $T$. The maximum reduction in $\phi_{t}$ is small (0.10), as a consequence of the high gas:solid ratio of FOAMGLAS $^{\circledast}$ (section 3.2.1). Isolated porosity $\left(\phi_{i}\right)$ also decreases systematically with $\varepsilon$, $\dot{\varepsilon}$, and $T$ (Figure 5 b, bottom). It is at a minimum $(\sim 0.60)$ in samples that showed stress drops during deformation (crosses in Figure 5).

If gas is conserved throughout deformation, the change in core volume $\left(V_{d}\right)$ is a consequence of the reduction in the total volume of gas-filled bubbles in the deformed foam. Figure $5 \mathrm{c}$ shows the normalized change in total pore volume $\left(\% \Delta V_{p}\right)$ against $\varepsilon$. Pore volume changes as a function of $\varepsilon, \dot{\varepsilon}$, and $T$. The greatest reduction in $\% \Delta V_{p}$ occurs in samples deformed quickly. Samples deformed at low $T$ show a greater reduction in $\Delta V_{p}$ than samples deformed a high $T$. The magnitude of $\% \Delta V_{p}$ is similar to $\varepsilon$.

Lastly, we measured the permeability of eight samples (Figure $5 \mathrm{~d}$ and Table 1). FOAMGLAS ${ }^{\circledast}$ cores deformed to variable strain $(\varepsilon=0.10-0.60)$ at $10^{-5} \mathrm{~s}^{-1}$ and moderate $T$ have final permeabilities below the detection limit of our permeameter, indicating permeabilities $\ll 10^{-18} \mathrm{~m}^{2}$. Subcores taken from the sample deformed at $10^{-3} \mathrm{~s}^{-1}$ to high strain (0.60) were cored in two orientations (parallel and perpendicular to the compression direction). These cores show microstructural evidence of strain localization perpendicular to the compression direction (discussed in detail in section 6). The permeabilities of subcores were $\ll 10^{-18} \mathrm{~m}^{2}$ and $7.34 \times 10^{-13} \mathrm{~m}^{2}$ when the strain localization plane was perpendicular and parallel to flow, respectively (Figure 5d). Permeability is strongly anisotropic in samples showing stress drops and evidence of strain localization (section 6).

Cores that did not show stress drops in the mechanical data have unoxidized interiors and show no evidence of microfracturing (section 6). Therefore, despite being deformed to high $\varepsilon$, at both variable $\dot{\varepsilon}$ and $T$, and showing marked changes in diameter, $V_{d}$ and $V_{p}$ (Table 1 and Figures 5a and 5c), our closed-cell bubble-rich melts remained impermeable during deformation.

\section{Microstructure Analysis}

Below we compare starting material (Figure 6a) and run products (Figures 6b-6h) to develop a microstructural explanation for the rheological behavior. 


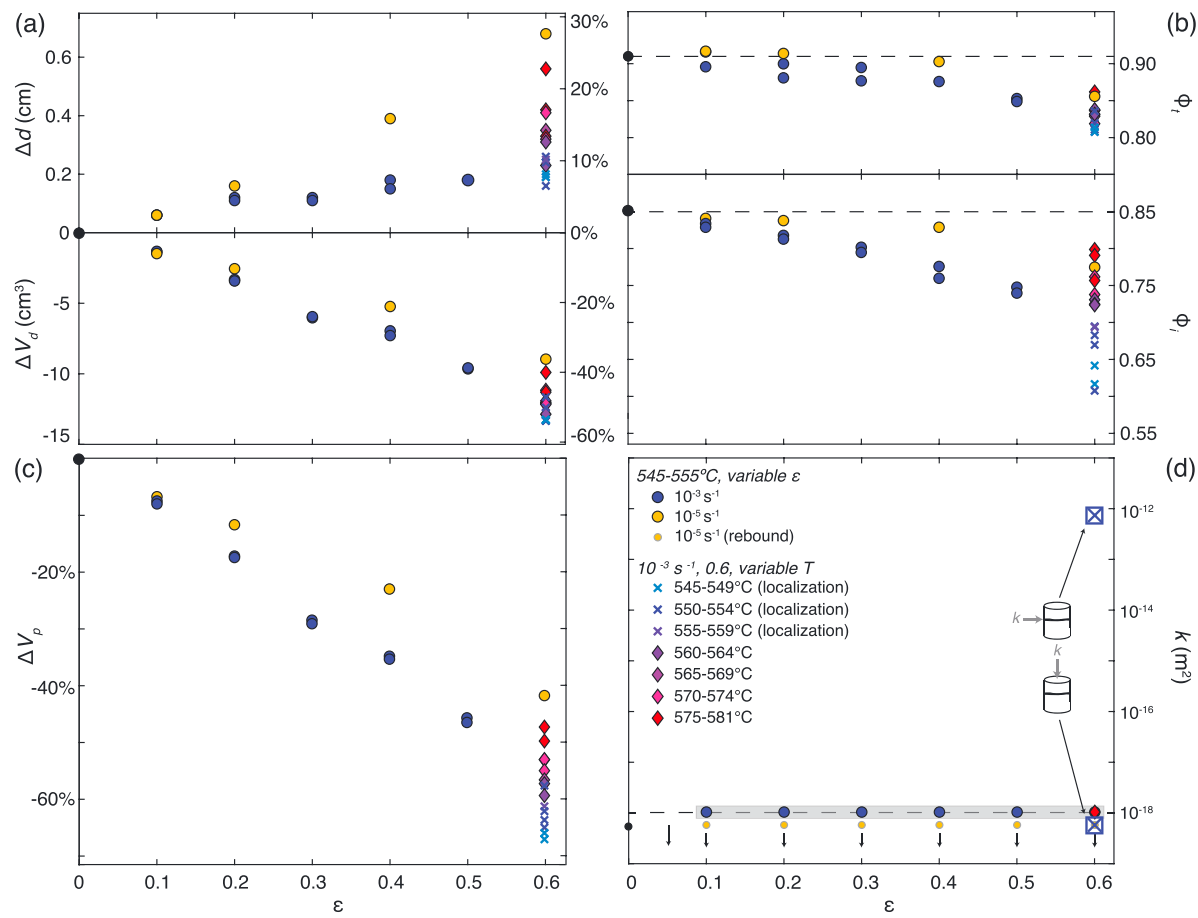

Figure 5. Physical properties. (a, top) Change in diameter $(\Delta d ; \mathrm{cm}$ and $\%)$ and (bottom) dimensional volume $\left(\Delta V_{d} ; \mathrm{cm}^{3}\right.$ and \%), against strain ( $\varepsilon$; fractional; Table 1). (b, top) Measured final total $\left(\phi_{t}\right)$ and (bottom) isolated porosities $\left(\phi_{i}\right)$ against $\varepsilon$ (Table 1). Dashed lines show initial total and isolated porosities. (c) The normalized change in total pore volume $\left(\Delta V_{p} ; \%\right)$ against $\varepsilon$. (d) Measured permeability $\left(k ; \mathrm{m}^{2}\right)$ against strain. For the initial material (black circle) and rebound samples (small yellow circles), the estimated $k$ is below the apparatus detection limit (dashed line at $10^{-18} \mathrm{~m}^{2}$ ). Most cores are estimated or inferred (grey box) to have permeabilities $\ll 10^{-18} \mathrm{~m}^{2}$. Large crosses show permeability of samples showing strain localization, measured perpendicular $\left(k \ll 10^{-18} \mathrm{~m}^{2}\right)$ and parallel to the plane of localization $(k=7.3 \times$ $10^{-13} \mathrm{~m}^{2}$; cartoons). Legend in (d).

\subsection{Geometric Effects}

Our experimental products show different microstructural patterns, depending on strain rate:

1. In samples deformed at moderate temperatures and a low strain rate $\left(10^{-5} \mathrm{~s}^{-1}\right)$, bubbles are flattened parallel to, and elongated perpendicular to, $\sigma_{1}$ (Figures $6 \mathrm{~b}$ and $6 \mathrm{c}$ ). With increasing $\varepsilon$ intensity of flattening/elongation increases to produce ellipsoidal to rectangular bubbles. Bubble walls perpendicular to $\sigma_{1}$ are elongate and straight. Bubble walls oriented at an acute angle to $\sigma_{1}$ are also nearly straight. The few walls parallel to $\sigma_{1}$ are bent and buckled. Small bubbles in bubble walls are still primarily subrounded to rounded, in some cases flattened perpendicular to $\sigma_{1}$.

2. Samples deformed at the same temperature, but more rapidly $\left(10^{-3} \mathrm{~s}^{-1}\right)$ contain contorted bubbles and folded bubble walls (Figures $6 \mathrm{~d}$ and $6 \mathrm{e}$ ). At moderate $\varepsilon$, bubbles do not show preferred flattening/elongation directions. Many bubble walls have buckled, and folded. With increasing $\varepsilon$, bubbles begin to flatten perpendicular to $\sigma_{1}$, and bubble walls perpendicular to $\sigma_{1}$ are generally straight. The remainder of bubble walls are intensely folded. Some small bubbles in the glass walls remain rounded, but others are folded or have irregular shapes.

The evolution of bubble wall geometry depends on temperature and strain rate. At constant temperatures, strain rate controls whether bubbles are (1) regular and ellipsoidal, with straight bubble walls (low $\dot{\varepsilon}$ ), or (2) irregular and contorted, with folded bubble walls (high $\dot{\varepsilon}$ ). Similarly, where strain rate is constant, increases or decreases in temperature cause bubbles to become (1) more regular in shape (Figure $6 \mathrm{~g}$ ) or (2) contorted (Figure 6f), respectively.

The development of the two geometries described above reflects the distribution of stresses in the samples, coupled with a dependence on $\dot{\varepsilon}$ and $T$. Walls oriented parallel to $\sigma_{1}$ are under compression and are likely to buckle. In contrast, walls oriented perpendicular to $\sigma_{1}$ are in tension and likely to stretch. However, as 
(a)

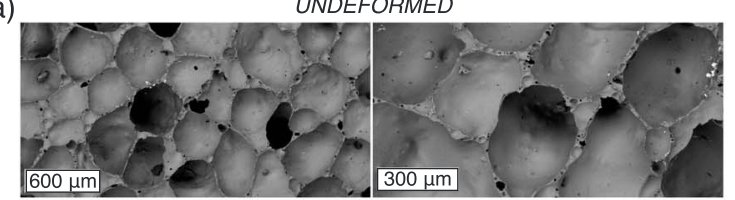

(b)

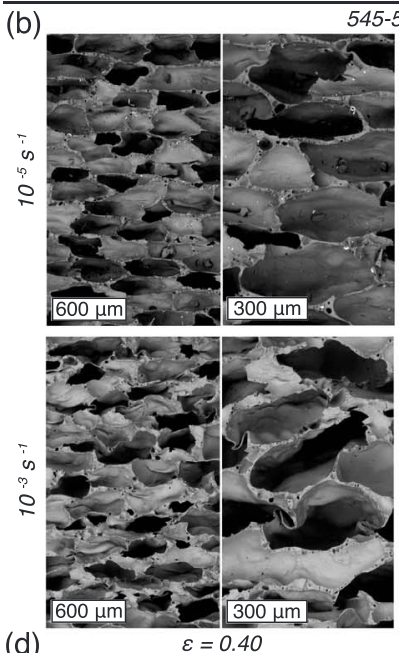

(d)

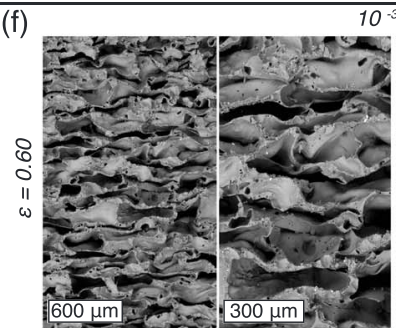

$540^{\circ} \mathrm{C}$

(h)
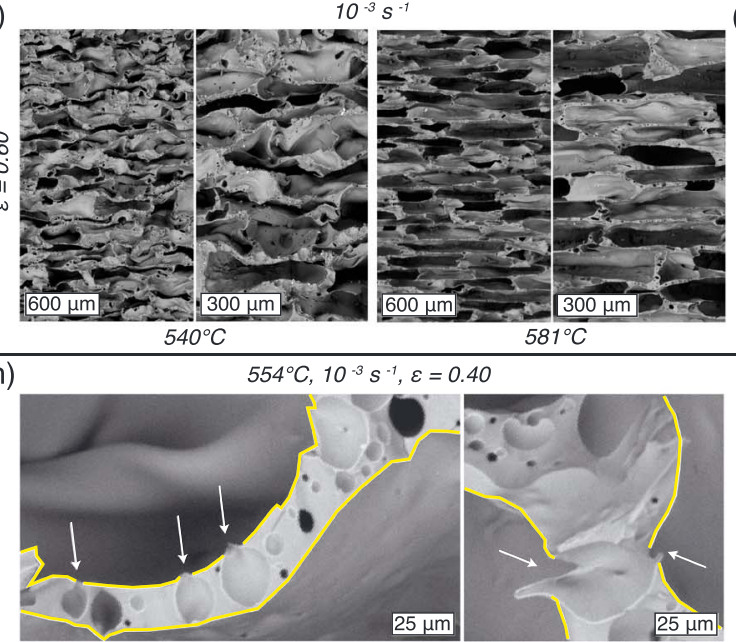

$581^{\circ} \mathrm{C}$
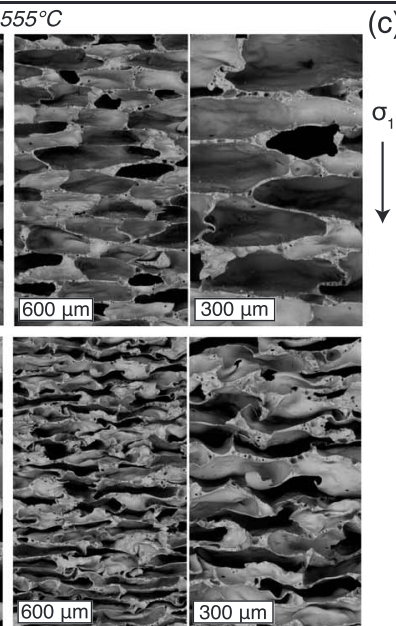

(e)

(g)

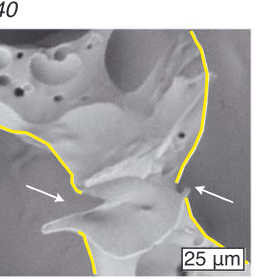

Figure 6. Bubble and bubble wall shapes. SEM images of each sample at two magnifications (scale bars in $\mu \mathrm{m}$ ). Deformation conditions listed above image pairs. The $\sigma_{1}$ shows the compression direction. (a) Undeformed FOAMGLAS ${ }^{\circledast}$. Large bubbles are polygonal to circular and near-equant. Bubble walls are straight to curved. (b) Large bubbles are slightly elongated perpendicular to $\sigma_{1}$, and shortened parallel to $\sigma_{1}$. Bubble walls are stretched and curvilinear. (c) At higher strain bubbles are more elongate perpendicular to $\sigma_{1}$, and shorter parallel to $\sigma_{1}$. Large bubbles are rectangular or elliptical. Most bubble walls are straight. Few are buckled. (d) At higher strain rates, large bubbles have complex shapes resulting from folding and buckling of bubble walls, both parallel and perpendicular to $\sigma_{1}$. (e) With increasing strain, bubble shapes become increasingly complex and generally elongate perpendicular to $\sigma_{1}$. Bubble walls oriented perpendicular to $\sigma_{1}$ are straight. Walls oriented parallel to $\sigma_{1}$ are intensely buckled and folded. (f) At the same strain rate and strain, and lower temperatures, bubble and bubble wall geometries are complex. (g) At higher temperatures bubble shapes are more regular and rectangular. Bubble walls are folded where oriented parallel to $\sigma_{1}$, but straight when oriented perpendicular to $\sigma_{1}$. (h) White arrows show torn melt films between small bubbles within the bubble wall (outlined in yellow) and adjacent large bubble(s). Sample is 328 , shown in (d). $\dot{\varepsilon}$ and $T$ increase and decrease, respectively, buckling of walls, even oriented perpendicular to $\sigma_{1}$, is more prevalent, particularly at low $\varepsilon$.

The shift between dominantly stretching and dominantly buckling coincides with the mechanical data and the physical properties of samples. Samples that show no strain weakening, pronounced bulging, and limited volume reduction contain ellipsoidal bubbles with straight bubble walls ((1) above) and were deformed at low $\dot{\varepsilon}$, or at high $\dot{\varepsilon}$ and high $T$. Conversely for samples where mechanical data include pronounced strain weakening, as well as limited bulging and significant volume reduction, bubbles have complex shapes with folded bubble walls ((2) above). These samples were deformed at high $\dot{\varepsilon}$ and moderate to low $T$.

It is notable that in most FOAMGLAS ${ }^{\circledast}$ samples deformation is distributed homogenously; at low to moderate strain, where strain weakening is observed, we see no zones of localized deformation. Similarly, as strain increases and hardening occurs, strain localization is not apparent in the microstructure of the samples except those that showed stress drops (see section 6.2).

Regardless of whether cores show stretching-dominant and bucklingdominant geometries, bubble walls are free of microfractures. This suggests deformation, involving both strain weakening and hardening, results from viscous flow of the melt component and is not a consequence of brittle micromechanisms.

\subsection{Causes of Acoustic Emissions}

We saw two types of $\mathrm{AE}$ events recorded during deformation (Figure 2 and section 4.3). Here we identify their causes:

Low-AE events occurred throughout deformation at high $\dot{\varepsilon}$ but did not correspond to strain weakening or hardening. As we observed no microfracturing of bubble walls, that is not the cause of low-AE events (Figure 6). Rather, low-AE events appear to result from the rupture of small bubbles within bubble walls (yellow outline, Figure $6 \mathrm{~h})$. In some samples thin films of melt $(<2 \mu \mathrm{m})$ separating small bubbles within walls from large bubbles are distended or torn (white arrows, Figure 6h). However, the greater bubble wall is intact (Figure 6h), indicating that rupturing does not result in an appreciable increase in bubble connectivity. This is confirmed by the low measured permeability of these samples (Figure 5d). To summarize, we posit low-AE events result from viscous tearing of thin films of melt.

In contrast, high-AE events correspond well with the mechanical data (Figure 3), and evidence strain localization and fracturing of melt walls. Photographs and scanning electron microscopy images of samples show the orientation, size, and position of strain localization bands (Figure 7a): the bands are thin and near-linear, crosscut the sample, and are oriented perpendicular to $\sigma_{1}$. In addition bands are oxidized (green). Thin "spurs" parallel to $\sigma_{1}$ terminate in the interior of the core. Scanning electron microscopy images show that bubble walls are disrupted in these $\sim 500-\mu \mathrm{m}$-wide regions (Figure $7 \mathrm{~b}$ ). Angular fragments of glass fill the available pore space. Outside the band, bubble walls remain intact (Figure 7b). 


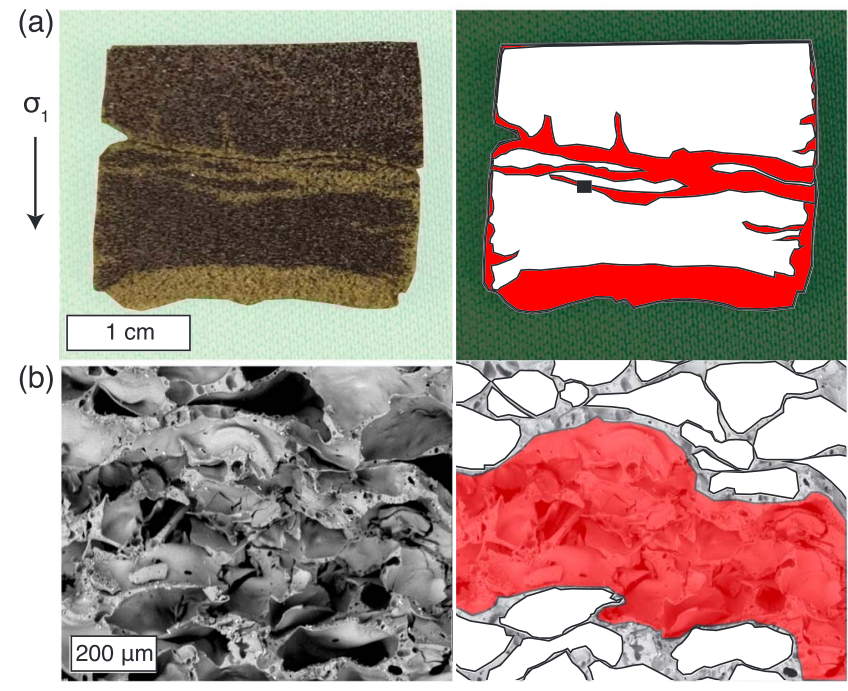

Figure 7. Compaction bands. (a) Photograph (left) of sample 311 (Table 1), showing green (oxidized) fractured regions, which form perpendicular to $\sigma_{1}$ and crosscut the sample. "Spurs" oriented parallel to $\sigma_{1}$ are only observed in this sample. Schematic (right) shows the band in red and the impermeable remainder of the core in white. Black box shows the position of (b). (b) SEM image (left) of a compaction band. Bubbles throughout sample are highly deformed and have complex shapes (Figure 6f). The compaction band is evidenced by disrupted, fractured bubble walls. Schematic (right) shows bubbles that appear intact as white shapes, and the area occupied by disrupted bubbles (compaction band) as a red zone. The width of the band is $\sim 500 \mu \mathrm{m}$.
These regions of strain localization are compaction bands and comprise planar structures characterized by a lower porosity than the host rock that are oriented at high angles to the compression direction (Wong \& Baud, 2012). Compaction bands are commonly observed in deformed porous materials (e.g., snow, polymers, metals, rocks), and have been shown to form as a result of the crushing of grains or the cataclastic collapse of pores/vesicles (e.g., Barraclough et al., 2017; Baud et al., 2004, 2006; Elliott et al., 2002; Fortin et al., 2006; Gibson \& Ashby, 1999; Heap, Farquharson, et al., 2015; Heap, Violay, et al., 2017; Issen et al., 2005; Papka \& Kyriakides, 1999; Wong et al., 1997, 2001; Wong \& Baud, 2012). The formation of compaction bands is often attended by stress drops and bursts of AE activity (Figures 2 and 3; e.g., Baud et al., 2004, 2006; Heap, Brantut, et al., 2015; Wong et al., 1997).

\section{Discussion}

Strain-dependent rheological behavior is relevant to the emplacement of silicic lavas-as lavas flow their response to deformation evolves and alters outgassing behavior (e.g., Kendrick et al., 2013; Shields et al., 2014). Below we explore the causes of strain-dependent rheological behaviors and their influences on outgassing mechanisms and efficiency.

\subsection{Melt Foam Rheology}

The mechanical behavior and microstructures of our experimental products change systematically with $\dot{\varepsilon}$ and $T$. During deformation at high strain rates bubbles become irregularly shaped, bubble walls fold, strain weakening occurs, and the foam is "soft" (low $\eta_{r}$ ). When deformed at low strain rates bubbles remain ellipsoidal, bubble walls are straight to curvilinear, no strain weakening occurs, and the composite is relatively "stiff" (high $\eta_{r}$ ). Increasing temperature reduces the magnitude of melt wall buckling and strain weakening, which causes the relative viscosity of the composite to rise.

In bubble suspensions, including many vesicular magmas and lavas, rheological behavior can be understood as a function of the steadiness of flow and the relaxation state of the bubbles (Mader et al., 2013, and references therein). In these materials, melt viscosity, bubble radius, and the interfacial tension between the fluid in bubbles and the melt $(\Gamma ; \mathrm{N} / \mathrm{m})$ dictate the bubble relaxation time $\left(\lambda_{b}=\left(\eta_{0} r\right) / \Gamma ; \mathrm{s}\right)$. Where $\lambda_{b}$ is less than the deformation time (related to the strain rate, $\dot{\varepsilon}$ ) interfacial forces act to reduce the surface energy and return bubbles to spherical shapes. At this condition, where interfacial forces dominate (i.e., where the capillary number $\left.\left(\mathrm{Ca}=\lambda_{b} \dot{\varepsilon}\right) \ll 1\right)$ spherical bubbles hinder viscous flow of the melt (Llewellin et al., 2002; Mader et al., 2013; Manga et al., 1998; Rust \& Manga, 2002). In contrast, where $\lambda_{b}$ is greater than the deformation time (i.e., $\mathrm{Ca} \gg 1$ ), the interfacial forces are low, and the dominating viscous forces deform the bubble. The change in bubble shape accompanying deformation introduces slip surfaces that allow the liquid to flow more easily (Llewellin et al., 2002; Mader et al., 2013; Manga et al., 1998; Rust \& Manga, 2002).

However, in melt foams ( $\phi_{t}>0.74$; Mader et al., 2013) where the total volume of gas present does not allow for the "packing" of spherical bubbles, the structure of the bubbly melt is different- "cells" of one fluid (here, $\mathrm{CO}_{2}$ gas) are surrounded by thin, near-planar films of a second fluid (here, silicate melt). This change in fluid structure, in turn, changes the rheological response (Mader et al., 2013). It is currently unknown how the relaxation state of the bubbles and steadiness of flow may influence foam rheology. Therefore, we use studies of other cellular solids and foams, rather than studies of bubble suspensions, to interpret our results.

Studies of the mechanics of elasto-plastic/viscoelastic cellular solids/foams (metals, polymers) have shown that, where deformation is homogenously distributed, changes in the geometry of cell walls introduce strain weakening and strain hardening behaviors (e.g., Gibson \& Ashby, 1999; Rashed et al., 2016). These studies identify three phases of compressive deformation: (1) elastic deformation during loading, (2) nonrecoverable cell wall stretching and/or buckling, and (3) densification at high strain. In the second phase, 
stretching versus buckling impart distinct $\sigma-\varepsilon$ patterns (e.g., Mu et al., 2010; Rashed et al., 2016; Scheffler \& Colombo, 2005): where stretching is dominant, $\sigma-\varepsilon$ curves reach a plateau following loading, but where bending/buckling dominate, strain weakening occurs as deformation proceeds. During densification, cell volumes decrease, bringing opposing or adjacent cell walls into contact (e.g., Gibson \& Ashby, 1999). During this final phase, increasing force is required for deformation to continue, resulting in strain hardening (Gibson \& Ashby, 1999; Mu et al., 2010; Rashed et al., 2016; Scheffler \& Colombo, 2005).

The relationship between FOAMGLAS ${ }^{\circledR}$ microstructure and rheological behavior therefore reflects the propensity for melt wall stretching or buckling. Where melt walls primarily stretch, a network of straight bubble walls forms, producing a relatively stiff (high $\eta_{r}$ ) foam. Deformation proceeds at a steady state until bubble walls are close enough to impinge on one another, at which point strain hardening begins. At conditions where melt walls primarily buckle rather than stretch, the foam is a network of folded bubble walls that is initially soft (low $\eta_{r}$ ). As it is compressed, bubble walls continue buckling, leading to strain weakening. Only when bubble walls impinge on one another at high strain does the foam harden.

The Deborah number $(D e)$ integrates the effects of $T$ and $\dot{\varepsilon}$ into a single parameter and is used, here, to delineate regimes for stretching versus buckling of bubble walls. Because the strain-dependent rheological behavior appears to be dictated by the compliance of the melt rather than to the behavior of the bulk foam material, we define $D e$ as the ratio of the Maxwell relaxation time of the melt $\left(\tau=\eta_{0} / G\right)$, where $G$ is the elastic shear modulus ( $10^{10} \mathrm{~Pa}$; Dingwell \& Webb, 1990) to the observation (or deformation) time ( $t$; e.g., Poole, 2012). Thus, it is a measure of the competition between the capacity of a melt to dissipate stress viscously (relax) and the rate at which deformation occurs:

$$
D e=\frac{\tau}{t}=\frac{\dot{\varepsilon} \eta_{0}}{G}
$$

Low $D e$ values correspond to effective dissipation of stress and melt relaxation. As $\eta_{0}$ and/or $\dot{\varepsilon}$ increase, viscous flow is hindered and stress accumulates in the melt. We adopt $D e \sim 10^{-2}$ as the transition from relaxed to unrelaxed states (i.e., Dingwell, 1996; Gonnermann \& Manga, 2003; Papale, 1999; Wadsworth et al., 2018).

In Figure 8 we plot $\eta_{r}$ against modeled $D e$. Representative mechanical data and microstructures are shown across our range of $D e$ values. There is a systematic relationship between $D e$, bubble wall geometry, bubble shape, and $\eta_{r}$, indicating that the propensity of bubble walls to stretch rather than buckle is controlled by the melt relaxation state: at low De numbers, the melt relaxes easily during deformation. At these conditions compliant bubble walls can stretch rather than buckle. In contrast, a reduced capacity to dissipate stress (i.e., higher De numbers) means bubble walls are less relaxed, less compliant, and buckle and fold rather than stretch.

The strain-dependent behavior of the foam also varies a function of $D e$. In particular strain weakening behaviors begin when $D e>10^{-3}$ (Figure 8 ). This is particularly consequential because the onset of strain weakening has been posited to create a feedback in the deformational behavior (Caricchi et al., 2011; Okumura et al., 2010; Wright \& Weinberg, 2009): as lava weakens during deformation, the same applied stress will promote higher local strain rates and greater strain (e.g., Vona et al., 2016). Localization and intensification of deformation can lead to a reduction in effective viscosity, facilitating further flow (Vona et al., 2016; Wright \& Weinberg, 2009). Studies of experimental and natural materials have shown that localized high strain rates can enhance bubble coalescence (Caricchi et al., 2011; Laumonier et al., 2011). Similarly, localization of deformation and concomitant increases in strain rate can force melt across the glass transition, causing brittle disruption of the melt and allowing outgassing (e.g., Okumura et al., 2010, 2013; Wright \& Weinberg, 2009).

In our study the onset of this weakening and localization behavior is evidenced by the high-permeability (relative to the host material) compaction bands formed in highly strained, unrelaxed foams (Figure 8): the compaction bands result when strain rates localized at bubble walls exceed the relaxation rates, causing fracture of the bubble walls (e.g., Dingwell \& Webb, 1990). Characteristically of compaction bands in many porous materials (including rocks, metals, snow, polymers; see Guillard et al. (2015) for extended discussion of compaction bands in brittle porous media), planar bands of localized strain are oriented perpendicular to $\sigma_{1}$, in this case as a result of the failure of melt walls, which propagated laterally (Figure $7 \mathrm{~b}$ ). This 


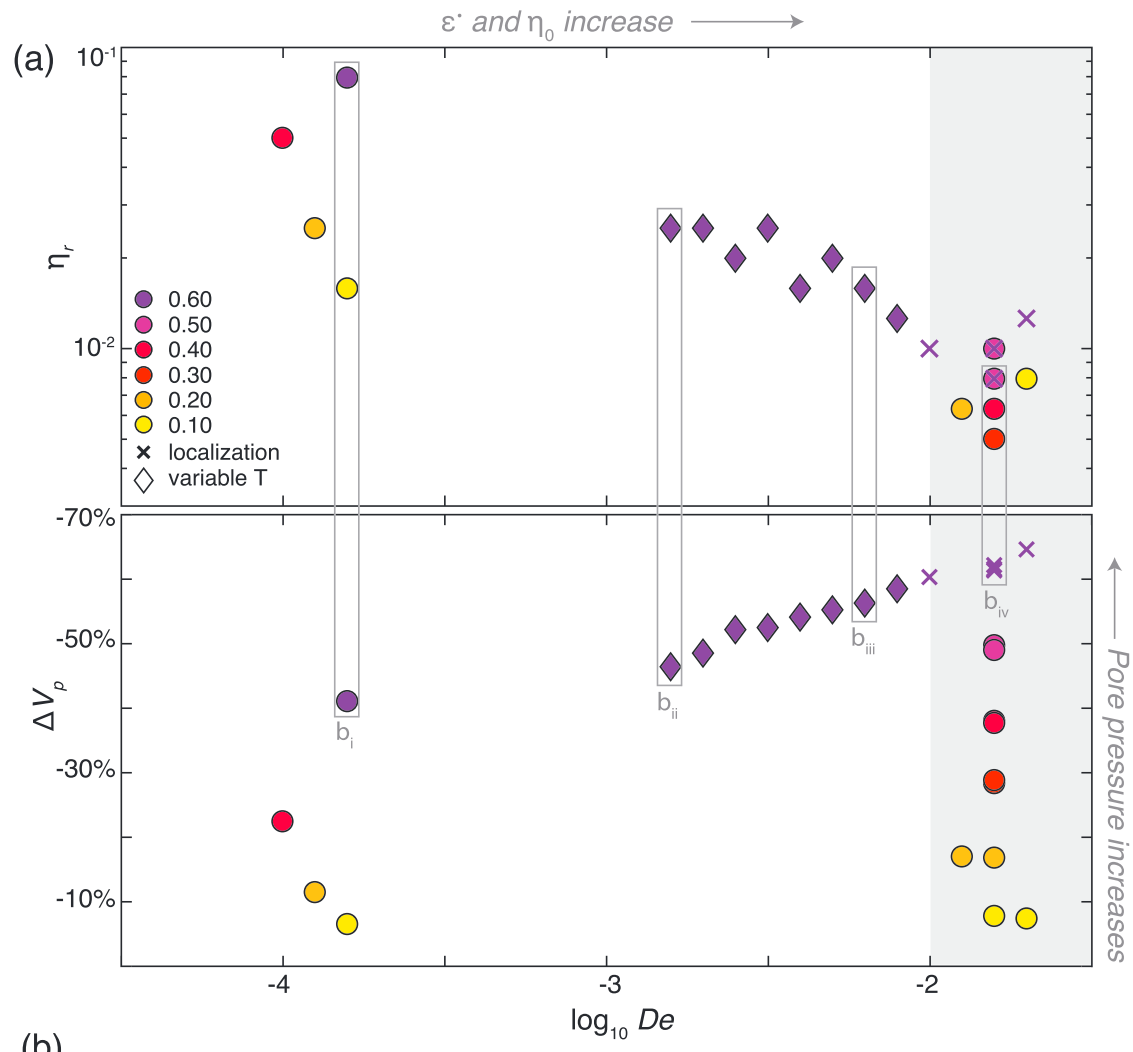

(b)

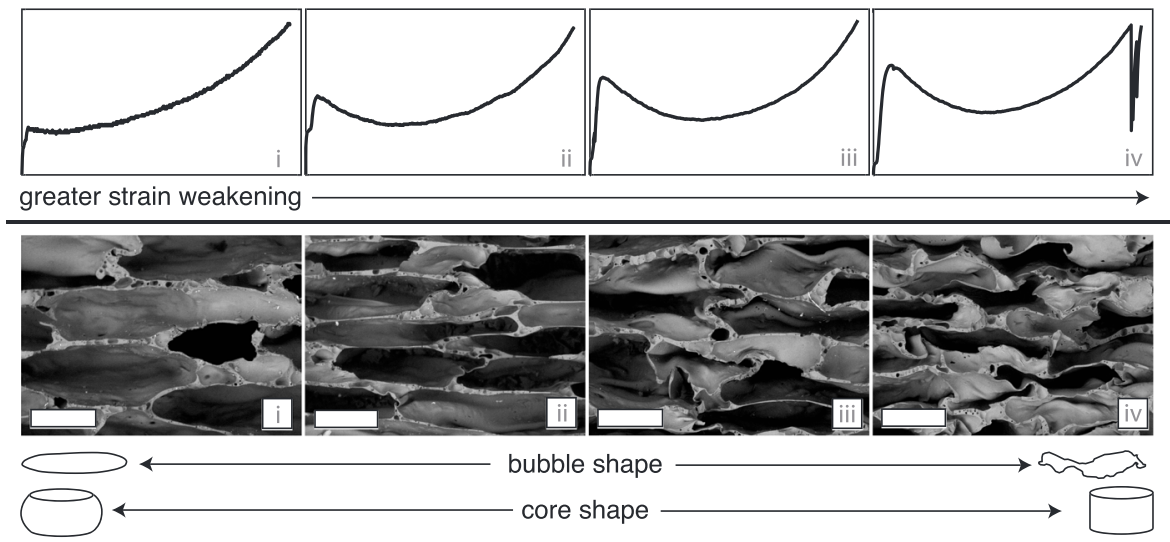

Figure 8. Microstructure, rheology, and outgassing as a function of Deborah number (De). At high $D e$, the melt is unrelaxed ( $D e>10^{-2}$; grey vertical zone). At low $D e$ the melt easily dissipates stress (relaxes). (a, top) Modeled relative viscosities $\left(\eta_{r}\right)$ against $D e$. Colors show strain, and crosses show samples with compaction bands (legend). At the same strain $\eta_{r}$ decreases with increasing $D e$. (a, bottom) Modeled changes in cumulative pore volume $\left(\Delta V_{p} ; \%\right)$ against $D e$. The reduction in pore volume increases with increasing strain, and as melt viscosity and/or strain rate increase (higher $D e$ ). (b, top) Representative mechanical data, corresponding to boxes in (a). As melt viscosities and strain rates increase (increasing De), samples show greater strain weakening. (b, bottom) Cartoons and SEM images showing the change in core and bubble shape, and microstructure with increasing $D e$ (boxes in (a)). Scale bars on SEM images are $200 \mu \mathrm{m}$. With increasing $D e$ bubble walls buckle, bubble shapes become contorted, and cores undergo less bulging.

micromechanism is similar to the cataclastic pore collapse described for porous limestones (e.g., Zhu et al., 2010) and volcanic rocks (e.g., Heap, Farquharson, et al., 2015; Heap, Violay, et al., 2017; Zhu et al., 2011). It is notable that compaction band formation in porous rocks typically requires high effective pressures (e.g., Wong \& Baud, 2012). The development of compaction bands deformed under uniaxial conditions, observed here and in other materials (e.g., polycarbonate honeycomb (Papka \& Kyriakides, 1999), closed-cell aluminum alloy foams (Bastawros et al., 2000)), may be a peculiarity of having a high total porosity ( $>0.74$ ). 
With strain weakening beginning at $D e>10^{-3}$, we can estimate that under a constant applied stress a feedback loop of weakening and effective viscosity reduction with increasing strain only needs to result in a tenfold increase in local deformation rate to drive a melt, including a natural silicic lava, to an unrelaxed state. At this condition brittle failure of bubble walls is feasible, and the outgassing behavior changes.

\subsection{Persistent Impermeability and Its Consequences}

Most of the experimental products remained impermeable despite being deformed (1) to high strain, (2) at both low and high strain rates, and (3) over melt viscosities spanning 1.5 orders of magnitude. These results speak to the surprising ability of melt foams to resist the formation of permeable pathways.

In FOAMGLAS ${ }^{\circledR}$, permeability increase only occurs when strain weakening and localization produce compaction bands in unrelaxed foams at high strain (Figures $5 \mathrm{~d}$ and 7 ). However, bubble walls are intact outside compaction bands - the remainder of the sample does not communicate with the band, and is impermeable. In porous rocks, compaction bands typically form barriers to fluid flow (e.g., Baud et al., 2012; Heap, Farquharson, et al., 2015; Wong et al., 2001; Wong \& Baud, 2012). For example, in porous sandstones, the compaction band is of lower permeability than the high-permeability host rock (e.g., Baud et al., 2012). However, because FOAMGLAS ${ }^{\circledR}$ is initially impermeable, compaction bands in our melt foam create a high-permeability channel and allow for fluid flow along their length. So although compaction bands represent areas of lower porosity (Figure 7b), they are also zones of higher vesicle connectivity (connectivity is zero in the remainder of the material), and are conduits for rather than barriers to flow.

Our results support the model that ephemeral permeable pathways may outgas silicic lavas (Figure 1b). Previous work has shown that this can be accomplished in simple shear by the coalescence of bubbles to form interconnected bubble networks (Caricchi et al., 2011; Okumura et al., 2009). In domains within lavas that undergo greater compaction (pure shear) than simple shear (e.g., Befus et al., 2015; Castro et al., 2002; Shields et al., 2016), compaction bands may also form and serve as permeable pathways. However the "extreme" flow conditions required for the formation of compaction bands (high strain, unrelaxed melt) makes them unlikely to form throughout flows. In addition, the permeability that has developed is anisotropic and is dictated by the orientation of $\sigma_{1}$ (permeability is still within error of zero perpendicular to the compaction band; Figure 5d). The efficacy of outgassing through compaction bands in a melt foam or lava will therefore depend on the orientation of the principal stresses, as well as the size and lateral extent of these bands, and connectivity to other fracture systems or the greater atmosphere (e.g., Castro, Cordonnier, et al., 2012; Heap \& Kennedy, 2016; Kushnir et al., 2017; Okumura et al., 2010; Shields et al., 2016).

The restricted flow conditions required for strain localization to occur, and the propensity of outgassing pathways to form with a particular orientation to the principal stresses are not the only hindrances to pervasive outgassing: both melt fractures and interconnected bubble networks are susceptible to closure and rapid healing (e.g., Kendrick et al., 2016; Kolzenburg et al., 2012; Lindoo et al., 2016; Rust \& Cashman, 2011; Shields et al., 2016; Tuffen et al., 2003; Yoshimura \& Nakamura, 2010). This suggests that other processes, such as diffusive dehydration and volatile resorption (e.g., McIntosh et al., 2014; Ryan et al., 2015; von Aulock et al., 2017; Westrich \& Eichelberger, 1994; Yoshimura et al., 2019; Yoshimura \& Nakamura, 2008), may be important mechanisms by which lavas, particularly silicic lavas, can outgas and densify (Figure 9a).

In the absence of efficient outgassing, fluids do not have a means of escaping the deforming melt foam. We see this in our experiments: during deformation, the $\mathrm{CO}_{2}$ contained in bubbles in FOAMGLAS ${ }^{\circledR}$ can either leave (i.e., outgas) or remain within bubbles. While compaction bands allow for some gas escape, gas loss can only occur by diffusive processes for the remainder of FOAMGLAS ${ }^{\circledR}$ samples. However, we have observed the expansion of deformed samples unloaded while above $T_{g}$ (section 2; Ryan et al., 2019). This indicates a pore pressure greater than atmospheric pressure, indicating that gas is conserved in our samples. Therefore, when bubbles in our samples are compressed during deformation, their volume change results in an increase in pore pressure, making $\Delta V_{p}$ an indicator of pore pressure changes.

Figure 8 shows the relationship between the change in total pore volume $\left(\Delta V_{p}\right)$ and $D e$, as well as representative core geometries. At low $D e$ conditions, where melt walls primarily stretch in response to deformation, cores bulge. Because the foam is translated laterally, in addition to being shortened, the resulting reduction in pore volume is $\sim 40 \%$. In contrast, at higher De conditions, melt walls primarily buckle and cores shorten 
Our model

"Persistent impermeability"

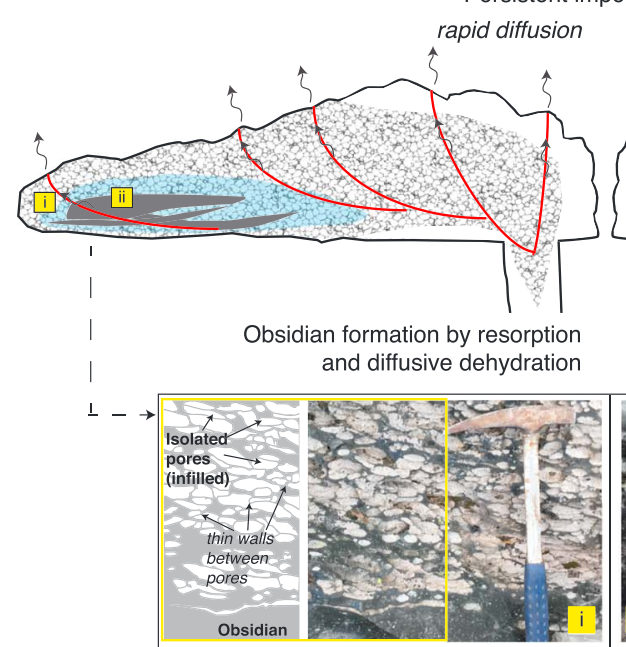

(b)

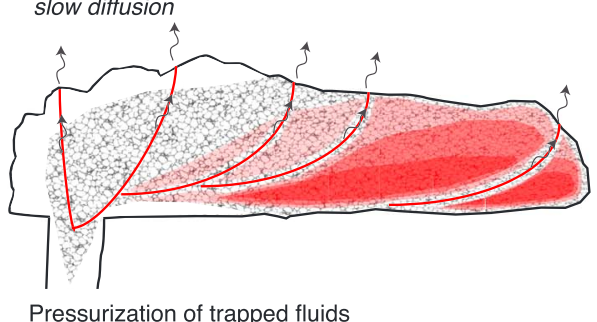

Pressurization of trapped fluids

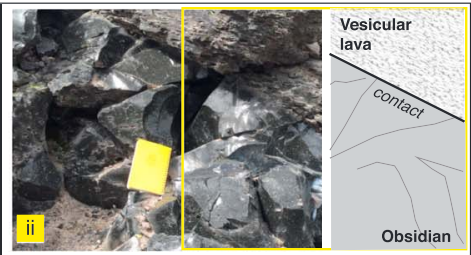

Figure 9. Consequences of "persistent impermeability" of silicic lavas. Schematics show a lava flow populated with isolated bubbles formed during syneruptive vesiculation. The lava is initially impermeable. In regions where strain rates and melt viscosity are high, the foam is unrelaxed and strain localization causes permeable pathways, such as compaction bands, to form (red lines). These pathways support localized outgassing (arrows). However, permeable pathways do not form in the remainder of the flow, and it remains impermeable. (a) Where diffusive processes (i.e., diffusive dehydration, volatile resorption) are rapid, they may allow for outgassing and densification to occur. Observed dense, nonvesicular lavas (obsidian; grey regions) may be formed by diffusive processes operating in the flow interior (blue region) rather than by outgassing through numerous permeable pathways (Figure 1b). Boxes mark locations in our hypothetical flow where textures observed in nature (at flow front of Little Glass Mountain, Medicine Lake Volcano, CA, USA) could be expected. These textures include (i) large, flattened, closely packed bubbles that appear to be isolated from one another (hammer for scale; see schematic at left). Bubble interiors are filled with precipitated/alteration materials (beige color infilling bubbles) that have uniform thickness along the interior surfaces, perhaps indicating that they accumulated on the inner surfaces while the bubbles remained isolated from one another and the atmosphere; (ii) thick band of dense obsidian containing few bubbles, bounded on its upper surface by vesicular lava containing many deformed vesicles (field book for scale; see schematic at right). The apparent connectivity between bubbles is not zero (as in (i)), but is low. Obsidian formation may result from diffusive dehydration, or by localized increases in bubble connectivity, leading to formation of ephemeral permeable pathways. (b) Where diffusive processes are slow, the core of the lava still contains compressible fluid-filled bubbles. As the lava flows and bubbles are compressed, pore pressures rise (red regions). Sudden unloading of this region can trigger far-field explosive activity (see section 7.3).

with limited bulging. This core geometry produces a larger reduction in total pore volume, up to $~ 65 \%$. Therefore, core geometry and $\Delta V_{p}$ (and pore pressure development) are governed by the state of melt wall relaxation. In unrelaxed melt foams $\left(D e>10^{-2}\right.$ ) the reductions in $\Delta V_{p}$ with strain are more pronounced and the rise in pore pressure is greater as deformation continues.

Applying our experimental insights to nature suggests that highly vesicular silicic lavas and magmas will retain their bubbles for extended times and have the potential to become overpressurized as a result of continued deformation (Figure 9b). This impermeable state will be maintained unless (1) specific flow conditions (high strain rates, low temperatures, high strain) are reached, supporting formation of numerous permeable pathways or (2) diffusive dehydration and resorption can moderate pore pressures.

\subsection{Implications for Outgassing and Explosivity of Rhyolitic Lavas}

We have shown that during compression at flow conditions expected for silicic lavas, outgassing of melt foams is inefficient - the foam does not transition from an impermeable to a permeable one, melt viscosities are not low enough to support coalescence (e.g., Castro, Burgisser, et al., 2012; Lindoo et al., 2016), and few permeable pathways form as a result of brittle behavior. Existing models for outgassing of silicic lavas (Figure 1) therefore appear to overestimate the outgassing potential of bubbly lavas.

The eruption of rhyolitic lava from Puyehue Cordón-Caulle (Chile) from 2011 to 2012 (Schipper et al., 2013; Tuffen et al., 2013) provides some evidence that lavas outgas very inefficiently. The lavas inflated during eruption, flow, and posteruption (Farquharson et al., 2015). Inflation, driven by late-stage vesiculation 
(i.e., volatile exsolution and bubble nucleation and growth occurring at Earth's surface), led to the formation of breakouts, and the progressive morphological change of the lava flow up to a year after the end of effusion (Farquharson et al., 2015; Magnall et al., 2018). The posteruption growth of the lava flow and the long runout distance are aided by the insulating properties of the flow surfaces (e.g., Farquharson et al., 2015; Magnall et al., 2018; Tuffen et al., 2013) but also could be facilitated by the long-term retention of bubbles: if lavas can flow for extended time without significant changes to their porosities, they maintain low effective viscosities orders of magnitude less than the viscosity of the melt. Sustained low effective viscosities promote efficient transport, allowing bubbly lavas to continue to deform and flow to produce extensive deposits.

Similarly, Holocene rhyolitic lavas preserve evidence of inefficient outgassing and the accumulation of trapped volatiles: for example, gas cavities and explosive craters mark the surfaces of rhyolitic flows hundreds of meters away from the vent (e.g., Big and Little Glass Mountains (Medicine Lake Volcano; CA, USA), Big Obsidian Flow (Newberry Volcano; OR, USA); Castro, Cashman, et al., 2002; Fink et al., 1992; Fink \& Anderson, 2017; Fink \& Manley, 1987). These features are interpreted as evidence of the retention and, in some cases, explosive release of pressurized gases trapped in the stalled and cooling lavas (Castro, Cashman, et al., 2002; Fink et al., 1992; Fink \& Manley, 1987). As such, they highlight the roles deformation and inefficient outgassing may play in causing hazardous behavior, including far-field explosivity. In addition, many of these Holocene flows contain both bands of dense obsidian, and thick layers of vesicular lavas (Fink \& Manley, 1987; Fink \& Anderson, 2017; see photos in Figure 9). These vesicular units, which can comprise up to $40 \%$ of the total flow volume in some large obsidian flows (Fink \& Manley, 1987), frequently contain isolated bubbles, attesting to the long-term retention of bubbles.

Finally, our interpretation of outgassing dynamics in melt foams offers additional clarity to the observation of hybrid volcanic activity-the contemporaneous effusion of lava and explosions-seen at the recent rhyolitic eruptions at Chaitén (2008-2009; Castro, Cordonnier, et al., 2012) and Puyehue Cordón Caulle (2011-2012; Schipper et al., 2013). Outgassing at these volcanoes is thought to be facilitated by the formation of fractures, which subsequently clog with pyroclastic debris and weld shut (e.g., Castro, Cordonnier, et al., 2012; Saubin et al., 2016; Heap et al., 2019), rather than through a permeable foam. The "persistent impermeability" of high-porosity foams, described herein, may explain why volatiles are forced to outgas through fracturing as soon as the pore overpressure is sufficient to fracture the magma.

In conclusion, we see from our experiments that melt foams do not undergo pervasive outgassing at conditions relevant to the flow of silicic lavas. We posit that natural lava flows remain gas-charged for longer than expected. Consequences of inefficient outgassing include extended runout distances for lavas and the potential for far-field explosive behavior.

\section{Conclusions}

We deformed a homogenous, impermeable analogue melt foam to explore the interplay between rheological behavior, microstructure, and outgassing, as functions of strain, strain rate, and temperature. We find that much of the deformational response of the closed-cell melt foam is dictated by the geometry of the melt walls, which is controlled by the capacity of the melt to dissipate stress and relax (i.e., De). The onset of strain weakening, driven by melt wall buckling, creates the potential for run-away deformation and can result in the formation of localized high-permeability zones.

Data are reported in Tables 1 and 2. This study was supported by the Natural Sciences and Engineering Research Council of Canada (NSERC) Discovery Grants program (RGPIN2018-03841; held by J.K. Russell). S. Kolzenburg acknowledges financial support from a H2020 Marie Skłodowska-Curie fellowship DYNAVOLC-795044. A. Vona acknowledges funding from the Grant of Excellence Departments, MIUR-Italy (art. 1, c. 314-337 1. 232/2016). We thank Patrick Baud for the discussions on compaction localization in porous materials. Finally, we thank the two anonymous reviewers who provided comments that helped us to improve the quality of this manuscript. The authors declare no conflicts of interest.
Pervasive outgassing did not occur in our experiments, although we deformed melt foam samples over a range of melt viscosities (Giordano et al., 2008) and strain rates applicable to natural lavas (Tuffen et al., 2003). Our results suggest that permeable pathways may not readily form in silicic lavas. Inefficient outgassing on the surface allows lavas to remain gas-charged for extended times, supporting longer flow distances, and perhaps feeding far-field explosivity. In the conduit, the inability to outgassing efficiently leaves the magma susceptible to pore pressurization and fragmentation in the subsurface.

\section{References}

Bagdassarov, N. S., \& Dingwell, D. B. (1992). A rheological investigation of vesicular rhyolite. Journal of Volcanology and Geothermal Research, 50(3), 307-322. https://doi.org/10.1016/0377-0273(92)90099-Y

Bagdassarov, N. S., Dingwell, D. B., \& Wilding, M. C. (1996). Rhyolite magma degassing: An experimental study of melt vesiculation. Bulletin of Volcanology, 57(8), 587-601. https://doi.org/10.1007/s004450050114 
Barraclough, T. W., Blackford, J. R., Liebenstein, S., Sandfeld, S., Stratford, T. J., Weinländer, G., \& Zaiser, M. (2017). Propagating compaction bands in confined compression of snow. Nature Physics, 13(3), 272-275. https://doi.org/10.1038/nphys3966

Bastawros, A.-F., Bart-Smith, H., \& Evans, A. G. (2000). Experimental analysis of deformation mehcanisms in closed-cell aluminum alloy foam. Journal of the Mechanics and Physics of Solids, 48(2), 301-322. https://doi.org/10.1016/S0022-5096(99)00035-6

Baud, P., Klein, E., \& Wong, T.-F. (2004). Compaction localization in porous sandstones: Spatial evolution of damage and acoustic emission activity. Journal of Structural Geology, 26(4), 603-624. https://doi.org/10.1016/j.jsg.2003.09.002

Baud, P., Meredith, P., \& Townend, E. (2012). Permeability evolution during triaxial compaction of an anisotropic porous sandstone. Journal of Geophysical Research, 117, B05203. https://doi.org/10.1029/2012JB009176

Baud, P., Vajdova, V., \& Wong, T.-F. (2006). Shear-enhanced compaction and strain localization: Inelastic deformation and constitutive modeling of four porous sandstones. Journal of Geophysical Research, 111, B12401. https://doi.org/10.1029/2005JB004101

Befus, K. S., Manga, M., Gardner, J. E., \& Williams, M. (2015). Ascent and emplacement dynamics of obsidian lavas inferred from microlite textures. Bulletin of Volcanology, 77(10), 88. https://doi.org/10.1007/s00445-015-0971-6

Burgisser, A., Chevalier, L., Gardner, J. E., \& Castro, J. M. (2017). The percolation threshold and permeability evolution of ascending magmas. Earth and Planetary Science Letters, 470, 37-47. https://doi.org/10.1016/j.epsl.2017.04.023

Burgisser, A., \& Gardner, J. E. (2005). Experimental constraints on degassing and permeability in volcanic conduit flow. Bulletin of Volcanology, 67, 42-56.

Cabrera, A., Weinberg, R. F., Wright, H. M. N., Zlotnik, S., \& Cas, R. A. F. (2011). Melt fracturing and healing: A mechanism for degassing and origin of silicic obsidian. Geology, 39(1), 67-70. https://doi.org/10.1130/G31355.1

Caricchi, L., Pommier, A., Pistone, M., Castro, J., Burgisser, A., \& Perugini, D. (2011). Strain-induced magma degassing: Insights from simple-shear experiments on bubble bearing melts. Bulletin of Volcanology, 73(9), 1245-1257. https://doi.org/10.1007/s00445-011-0471-2

Castro, J., Cashman, K., Joslin, N., \& Olmsted, B. (2002). Structural origin of large gas cavities in the Big Obsidian Flow, Newberry Volcano. Journal of Volcanology and Geothermal Research, 114(3-4), 313-330. https://doi.org/10.1016/S0377-0273(01)00296-7

Castro, J., Manga, M., \& Cashman, K. (2002). Dynamics of obsidian flows inferred from microstructures: Insights from microlite preferred orientations. Earth and Planetary Science Letters, 199(1-2), 211-226. https://doi.org/10.1016/S0012-821X(02)00559-9

Castro, J. M., Bindeman, I. N., Tuffen, H., \& Schipper, C. I. (2014). Explosive origin of silicic lava: Textural and $\delta D-H_{2} \mathrm{O}$ evidence for pyroclastic degassing during rhyolite effusion. Earth and Planetary Science Letters, 405, 52-61. https://doi.org/10.1016/j.epsl.2014.08.012

Castro, J. M., Burgisser, A., Schipper, C. I., \& Mancini, S. (2012). Mechanisms of bubble coalescence in silicic magmas. Bulletin of Volcanology, 74(10), 2339-2352. https://doi.org/10.1007/s00445-012-0666-1

Castro, J. M., Cordonnier, B., Tuffen, H., Tobin, M. J., Puskar, L., Martin, M. C., \& Bechtel, H. A. (2012). The role of melt-fracture degassing in defusing explosive rhyolite eruptions at volcán Chaitén. Earth and Planetary Science Letters, 333-334, 63-69.

Dingwell, D. B. (1996). Volcanic dilemma: Flow or blow? Science, 273(5278), 1054-1055. https://doi.org/10.1126/science.273.5278.1054

Dingwell, D. B., \& Webb, S. L. (1990). Relaxation in silicate melts. European Journal of Mineralogy, 2(4), 427-451. https://doi.org/10.1127/ ejm/2/4/0427

Eichelberger, J. C., Carrigan, C. R., Westrich, H. R., \& Price, R. H. (1986). Non-explosive silicic volcanism. Nature, 323(6089), 598-602. https://doi.org/10.1038/323598a0

Elliott, J. A., Windle, A. H., Hobdell, J. R., Eeckhaut, G., Oldman, R. J., Ludwig, W., et al. (2002). In-situ deformation of an open-cell flexible polyurethane foam characterised by 3D computed microtomography. Journal of Materials Science, 37(8), 1547-1555. https://doi.org/ 10.1023/A:1014920902712

Farquharson, J. I., James, M. R., \& Tuffen, H. (2015). Examining rhyolite lava flow dynamics through photo-based 3D reconstructions of the 2011-2012 lava flowfield at Cordón-Caulle, Chile. Journal of Volcanology and Geothermal Research, 304, 336-348. https://doi.org/ 10.1016/j.jvolgeores.2015.09.004

Fink, J.H. \& Anderson, S.W. (2017). Emplacement of Holocene silicic lava flows and domes at Newberry, South Sister, and Medicine Lake volcanoes, California and Oregon. United States Geological Survey, Scientific Investigations Report 2017-5022-I.

Fink, J. H., Anderson, S. W., \& Manley, C. R. (1992). Textural constraints on effusive silicic volcanism: Beyond the permeable foam model Journal of Geophysical Research, 97(B6), 9073-9083. https://doi.org/10.1029/92JB00416

Fink, J. H., \& Manley, C. R. (1987). Origin of pumiceous and glassy textures in rhyolite flows and domes. Geological Society of America Special Paper, 212, 77-88. https://doi.org/10.1130/SPE212-p77

Fortin, J., Stanchits, S., Dresen, G., \& Guéguen, Y. (2006). Acoustic emission and velocities associated with the formation of compaction bands in sandstone. Journal of Geophysical Research, 111, B10203. https://doi.org/10.1029/2005JB003854

Giachetti, T., Gonnermann, H. M., Gardner, J. E., Burgisser, A., Hajimirza, S., Earley, T. C., et al. (2019). Bubble coalescence and percolation threshold in expanding rhyolitic magma. Geochemistry, Geophysics, Geosystems, 20, 1054-1074. https://doi.org/10.1029/2018GC008006

Gibson, L. J., \& Ashby, M. F. (1999). Cellular solids: Structure and properties (2nd ed.). Cambridge UK: Cambridge University Press.

Giordano, D., Russell, J. K., \& Dingwell, D. B. (2008). Viscosity of magmatic liquids: A model. Earth and Planetary Science Letters, 271(1-4), 123-134. https://doi.org/10.1016/j.epsl.2008.03.038

Gonnermann, H. M., Giachetti, T., Fliedner, C., Nguyen, C. T., Houghton, B. F., Crozier, J. A., \& Carey, R. J. (2017). Permeability during magma expansion and compaction. Journal of Geophysical Research: Solid Earth, 122, 9825-9848. https://doi.org/10.1002/2017JB014783

Gonnermann, H. M., \& Manga, M. (2003). Explosive volcanism may not be an inevitable consequence of magma fragmentation. Nature, 426(6965), 432-435. https://doi.org/10.1038/nature02138

Guillard, F., Golshan, P., Shen, L., Valdes, J. R., \& Einav, I. (2015). Dynamic patters of compaction in brittle porous media. Nature Physics, 11(10), 835-838. https://doi.org/10.1038/nphys3424

Heap, M. J., Brantut, N., Baud, P., \& Meredith, P. G. (2015). Time-dependent compaction band formation in sandstone. Journal of Geophysical Research: Solid Earth, 120, 4808-4830. https://doi.org/10.1002/2015JB012022

Heap, M. J., Farquharson, J. I., Baud, P., Lavallée, Y., \& Reuschlé, T. (2015). Fracture and compaction of andesite in a volcanic edifice. Bulletin of Volcanology, 77(6), 55. https://doi.org/10.1007/s00445-015-0938-7

Heap, M. J., \& Kennedy, B. M. (2016). Exploring the scale-dependent permeability of fractured andesite. Earth and Planetary Science Letters, 447, 139-150. https://doi.org/10.1016/j.epsl.2016.05.004

Heap, M. J., Kushnir, A. R. L., Gilg, H. A., Wadsworth, F. B., Reuschlé, T., \& Baud, P. (2017). Microstructural and petrophysical properties of the Permo-Triassic sandstones (Buntsandstein) from the Soultz-sous-Forêts geothermal site (France). Geothermal Energy, 5(1), 26. https://doi.org/10.1186/s40517-017-0085-9

Heap, M. J., Tuffen, H., Wadsworth, F. B., Reuschlé, T., Castro, J. M., \& Schipper, C. I. (2019). The permeability evolution of tuffisites and implications for outgassing through dense rhyolitic magma. Journal of Geophysical Research: Solid Earth, 124. https://doi.org/10.1029/ 2018JB017035 
Heap, M. J., Violay, M., Wadsworth, F. B., \& Vasseur, J. (2017). From rock to magma and back again: The evolution of temperature and deformation mechanism in conduit margin zones. Earth and Planetary Science Letters, 463, 92-100. https://doi.org/10.1016/j. epsl.2017.01.021

Issen, K. A., Casey, T. P., Dixon, D. M., Richards, M. C., \& Ingraham, J. P. (2005). Characterization and modeling of localized compaction in aluminum foam. Scripta Materialia, 52(9), 911-915. https://doi.org/10.1016/j.scriptamat.2004.12.031

Kendrick, J. E., Lavallée, Y., Hess, K.-U., Heap, M. J., Gaunt, H. A., Meredith, P. G., \& Dingwell, D. B. (2013). Tracking the permeable porous network during strain-dependent magmatic flow. Journal of Volcanology and Geothermal Research, 260, 117-126. https://doi. org/10.1016/j.jvolgeores.2013.05.012

Kendrick, J. E., Lavallée, Y., Varley, N. R., Wadsworth, F. B., Lamb, O. D., \& Vasseur, J. (2016). Blowing off steam: Tuffisite formation as a regulator for lava dome eruptions. Frontiers in Earth Science, 4, 41.

Kolzenburg, S., Heap, M. J., Lavallée, Y., Russell, J. K., Meredith, P. G., \& Dingwell, D. B. (2012). Strength and permeability recovery of tuffisite-bearing andesite. Solid Earth, 3(2), 191-198. https://doi.org/10.5194/se-3-191-2012

Kushnir, A. R. L., Heap, M. J., \& Baud, P. (2018). Assessing the role of fracture on the permeability of the Permo-Triassic sandstones at Soultz-sous-Forêts (France) geothermal site. Geothermics, 74, 181-189. https://doi.org/10.1016/j.geothermics.2018.03.009

Kushnir, A. R. L., Martel, C., Champallier, R., \& Arbaret, L. (2017). In situ confirmation of permeability development in shearing bubblebearing melts and implications for volcanic outgassing. Earth and Planetary Science Letters, 458, 315-326. https://doi.org/10.1016/j. epsl.2016.10.053

Laumonier, M., Arbaret, L., Burgisser, A., \& Champallier, P. (2011). Porosity redistribution enhanced by strain localization in crystal-rich magmas. Geology, 39(8), 715-718. https://doi.org/10.1130/G31803.1

Lindoo, A., Larsen, J. F., Cashman, K. V., Dunn, A. L., \& Neill, O. K. (2016). An experimental study of permeability development as a function of crystal-free melt viscosity. Earth and Planetary Science Letters, 435, 45-54. https://doi.org/10.1016/j.epsl.2015.11.035

Llewellin, E. W., Mader, H. M., \& Wilson, S. D. R. (2002). The constitutive equation and flow dynamics of bubbly magmas. Geophysical Research Letters, 29(24), 2170. https://doi.org/10.1029/2002GL015697

Mader, H. M., Llewellin, E. W., \& Mueller, S. P. (2013). The rheology of two-phase magmas: A review and analysis. Journal of Volcanology and Geothermal Research, 257, 135-158. https://doi.org/10.1016/j.jvolgeores.2013.02.014

Magnall, N., James, M. R., Tuffen, H., Vye-Brown, C., Schipper, C. I., Castro, J. M., \& Davies, A. G. (2018). The origin and evolution of breakouts in a cooling-limited rhyolite lava flow. Geological Society of America Bulletin, 131(1-2), 137-154. https://doi.org/10.1130/B31931.1

Manga, M., Castro, J., Cashman, K. V., \& Loewenberg, M. (1998). Rheology of bubble-bearing magmas. Journal of Volcanology and Geothermal Research, 87(1-4), 15-28. https://doi.org/10.1016/S0377-0273(98)00091-2

Martel, C., \& Iacono-Marziano, G. (2015). Timescales of bubble coalescence, outgassing, and foam collapse in decomrpessed rhyolitic melts. Earth and Planetary Science Letters, 412, 173-185. https://doi.org/10.1016/j.epsl.2014.12.010

McIntosh, I. M., Llewellin, E. W., Humphreys, M. C. S., Nichols, A. R. L., Burgisser, A., Schipper, C. I., \& Larsen, J. F. (2014). Distribution of dissolved water in magmatic growth records growth and resorption of bubbles. Earth and Planetary Science Letters, 401, 1-11. https:// doi.org/10.1016/j.epsl.2014.05.037

Mu, Y., Yao, G., Liang, L., Luo, H., \& Zu, G. (2010). Deformation mechanisms of closed-cell aluminum foam in compression. Scripta Materialia, 63(6), 629-632. https://doi.org/10.1016/j.scriptamat.2010.05.041

Okumura, S., Nakamura, M., Nakano, T., Uesugi, K., \& Tsuchiyama, A. (2010). Shear deformation experiments on vesicular rhyolite: Implications for brittle fracturing, degassing, and compaction of magmas in volcanic conduits. Journal of Geophysical Research, 115 , B06201. https://doi.org/10.1029/2009JB006904

Okumura, S., Nakamura, M., Takeuchi, S., Tsuchiyama, A., Nakano, T., \& Uesugi, K. (2009). Magma deformation may induce nonexplosive volcanism via degassing through bubble networks. Earth and Planetary Science Letters, 281(3-4), 267-274. https://doi.org/ 10.1016/j.epsl.2009.02.036

Okumura, S., Nakamura, M., Uesugi, K., Nakano, T., \& Fujioka, T. (2013). Coupled effect of magma degassing rheology on silicic volcanism. Earth and Planetary Science Letters, 362, 163-170. https://doi.org/10.1016/j.epsl.2012.11.056

Papale, P. (1999). Strain-induced magma fragmentation in explosive eruptions. Nature, 397(6718), 425-428. https://doi.org/10.1038/17109

Papka, S. D., \& Kyriakides, S. (1999). Biaxial crushing of honeycombs: Part I-Experiments. International Journal of Solids and Structures, 36(29), 4367-4396. https://doi.org/10.1016/S0020-7683(98)00224-8

Poole, R. J. (2012). The Deborah and Weissenbyerg numbers. Rheology Bulletin, 52, 32-39.

Quane, S. L., Russell, J. K., \& Kennedy, L. A. (2004). A low-load, high-temperature deformation apparatus for volcanological studies. American Mineralogist, 89(5-6), 873-877. https://doi.org/10.2138/am-2004-5-622

Rashed, M. G., Ashraf, M., Mines, R. A. W., \& Hazell, P. J. (2016). Metallic microlattice materials: A current state of the art on manufacturing, mechanical properties and applications. Materials and Design, 95, 518-533. https://doi.org/10.1016/j.matdes.2016.01.146

Rust, A. C., \& Cashman, K. V. (2004). Permeability of vesicular silicic magma: Inertial and hysteresis effects. Earth and Planetary Science Letters, 228(1-2), 93-107. https://doi.org/10.1016/j.epsl.2004.09.025

Rust, A. C., \& Cashman, K. V. (2011). Permeability controls on expansion and size distributions of pyroclasts. Journal of Geophysical Research, 116, B11202. https://doi.org/10.1029/2011JB008494

Rust, A. C., \& Manga, M. (2002). Effects of bubble deformation on the viscosity of dilute suspensions. Journal of Non-Newtonian Fluid Mechanics, 104(1), 53-63. https://doi.org/10.1016/S0377-0257(02)00013-7

Ryan, A. G., Kolzenburg, S., Vona, A., Heap, M. J., Russell, J. K., \& Badger, S. (2019). A proxy for magmatic foams: FOAMGLAS ${ }^{\circledast}$, a closedcell glass insulation. Journal of Non-Crystalline Solids: X, 1. https://doi.org/10.1016/j.nocx.2018.100001

Ryan, A. G., Russell, J. K., Nichols, A. R. L., Hess, K.-U., \& Porritt, L. A. (2015). Experiments and models on $\mathrm{H}_{2} \mathrm{O}$ retrograde solubility in volcanic systems. American Mineralogist, 100(4), 774-786. https://doi.org/10.2138/am-2015-5030

Saubin, E., Tuffen, H., Gurioli, L., Owen, J., Castro, J. M., Berlo, K., et al. (2016). Conduit dynamics in transitional rhyolitic activity recorded by tuffisite vein textures from the 2008-2009 Chaiten eruption. Frontiers in Earth Science, 4. https://doi.org/10.3389/ feart.2016.00059

Scheffler, M., \& Colombo, P. (2005). Cellular ceramics: Structure, manufacturing, properties and applications. Weinheim Germany: WILEYVCH. https://doi.org/10.1002/3527606696

Schipper, C. I., Castro, J. M., Tuffen, H., James, M. R., \& How, P. (2013). Shallow vent architecture during hybrid explosive-effusive activity at Cordón Caulle (Chile, 2011-2012): Evidence from direct observations and pryoclast textures. Journal of Volcanology and Geotherma Research, 262, 25-37. https://doi.org/10.1016/j.jvolgeores.2013.06.005

Shields, J. K., Mader, H. M., Caricchi, L., Tuffen, H., Mueller, S., Pistone, M., \& Baumgartner, L. (2016). Unravelling textural heterogeneity in obsidian: Shear-induced outgassing in the Rocche Rosse flow. Journal of Volcanology and Geothermal Research, 230, 137-158. 
Shields, J. K., Mader, H. M., Pistone, M., Caricchi, L., Floess, D., \& Putlitz, B. (2014). Strain-induced outgassing of three-phase magmas during simple shear. Journal of Geophysical Research: Solid Earth, 119, 6936-6957. https://doi.org/10.1002/2014JB011111

Sicola, S. (2018). The role of degassing in eruptive dynamics and its influence on magma rheology (Doctoral dissertation). Rome, Italy: Università degli Studi Roma Tre.

Stevenson, R. J., Bagdassarov, N. S., \& Romano, C. (1997). Vesiculation processes in a water-rich calc-alkaline obsidian. Earth and Planetary Science Letters, 146(3-4), 555-571. https://doi.org/10.1016/S0012-821X(96)00236-1

Takeuchi, S., Tomiya, A., \& Shinohara, H. (2009). Degassing conditions for permeable silicic magmas: Implications from decompression experiments with constant rates. Earth and Planetary Science Letters, 283, 101-110.

Tuffen, H., Dingwell, D. B., \& Pinkerton, H. (2003). Repeated fracture and healing of silicic magma generate flow banding and earthquakes? Geology, 31(12), 1089-1092. https://doi.org/10.1130/G19777.1

Tuffen, H., James, M. R., Castro, J. M., \& Schipper, C. I. (2013). Exceptional mobility of an advancing rhyolitic obsidian flow at Cordón Caulle volcano in Chile. Nature Communications, 4(1), 2709. https://doi.org/10.1038/ncomms3709

von Aulock, F. W., Kennedy, B. M., Maksimenko, A., Wadsworth, F. B., \& Lavallée, Y. (2017). Outgassing from open and closed magma Foams. Frontiers in Earth Science, 5, 46. https://doi.org/10.3389/feart.2017.00046

Vona, A., Ryan, A. G., Russell, J. K., \& Romano, C. (2016). Models for viscosity and shear localization in bubble-rich magmas. Earth and Planetary Science Letters, 449, 26-38. https://doi.org/10.1016/j.epsl.2016.05.029

Wadsworth, F. B., Witcher, T., Vossen, C. E. J., Hess, K.-U., Unwin, H. E., Scheu, B., et al. (2018). Combined effusive-explosive silicic volcanism straddles the multiphase viscous-to-brittle transition. Nature Communications, 9(1), 4696. https://doi.org/10.1038/s41467018-07187-w

Westrich, H. R., \& Eichelberger, J. C. (1994). Gas transport and bubble collapse in rhyolitic magma: An experimental approach. Bulletin of Volcanology, 56(6-7), 447-458. https://doi.org/10.1007/BF00302826

Wong, T.-F., \& Baud, P. (2012). The brittle-ductile transition in porous rock: A review. Journal of Structural Geology, 44, 25-53. https://doi. org/10.1016/j.jsg.2012.07.010

Wong, T.-F., Baud, P., \& Klein, E. (2001). Localized failure modes in compactant porous rock. Geophysical Research Letters, 28(13), 2521-2524. https://doi.org/10.1029/2001GL012960

Wong, T.-F., David, C., \& Zhu, W. (1997). The transition from brittle faulting to cataclastic flow in porous sandstones: Mechanical deformation. Journal of Geophysical Research, 102(B2), 3009-3025. https://doi.org/10.1029/96JB03281

Wright, H. M. N., \& Weinberg, R. F. (2009). Strain localization in vesicular magma: Implications for rheology and fragmentation. Geology, 37(11), 1023-1026. https://doi.org/10.1130/G30199A.1

Yoshimura, S., Kuritani, T., Matsumoto, A., \& Nakagawa, M. (2019). Fingerprint of silicic magma degassing visualised through chlorine microscopy. Scientific Reports, 9(1), 786. https://doi.org/10.1038/s41598-018-37374-0

Yoshimura, S., \& Nakamura, M. (2008). Diffusive dehydration and bubble resorption during open-system degassing of rhyolitic melts. Journal of Volcanology and Geothermal Research, 178(1), 72-80. https://doi.org/10.1016/j.jvolgeores.2008.01.017

Yoshimura, S., \& Nakamura, M. (2010). Fracture healing in a magma: An experimental approach and implications for volcanic seismicity and degassing. Journal of Geophysical Research, 115, B09209. https://doi.org/10.1029/2009JB000834

Zhu, W., Baud, P., Vinciguerra, S., \& Wong, T.-F. (2011). Micromechanics of brittle faulting and cataclastic flow in Alban Hills tuff. Journal of Geophysical Research, 116, B06209. https://doi.org/10.1029/2010JB008046

Zhu, W., Baud, P., \& Wong, T.-F. (2010). Micromechanics of cataclastic pore collapse in limestone. Journal of Geophysical Research, 115, B04405. https://doi.org/10.1029/2009JB006610 